Open Access

\title{
Exploring science-and-technology-led innovation: a cross-country study
}

Viju Raghupathi ${ }^{{ }^{*}}$ and Wullianallur Raghupathi ${ }^{2}$

\author{
* Correspondence: \\ VRaghupathi@brooklyn.cuny.edu \\ ${ }^{1}$ Koppelman School of Business, \\ Brooklyn College of the City \\ University of New York, 2900 \\ Bedford Ave, Brooklyn, NY 11210, \\ USA \\ Full list of author information is \\ available at the end of the article
}

\begin{abstract}
Countries can enhance endogenous innovation using multifaceted incentives for science and technology indicators. We explore country-level innovation using OECD data for research and development (R\&D), patents, and exports. We deploy a dual methodology of descriptive visualization and panel regression analysis. Our results highlight industry variances in R\&D spending. As a nation develops, governmental expenditure on R\&D decreases, and businesses take on an increasing role to fill the gap, increasing local innovation. Our portfolio of local versus foreign resident ownership of patents highlights implications for taxation/innovation policies. Countries with high foreign ownership of patents have low tax revenues due to the lack of associated costs with, and mobility of income from, patents. We call on these countries to devise targeted policies encouraging local patent ownership. Policy makers should also recognize factors influencing high-technology exports for innovation. Lastly, we call on countries to reinstate horizontal and vertical policies, and design national innovation ecosystems that integrate disparate policies in an effort to drive economic growth through innovation.
\end{abstract}

Keywords: Innovation, Patents, Science and technology, Research and development, Exports, Panel analysis

\section{Introduction}

Innovation is a key driver of economic growth and a prime source of competition in the global marketplace (Organization for Economic Cooperation and Development (OECD) 2005); at least 50\% of growth is attributable to it (Kayal 2008; Organization for Economic Cooperation and Development (OECD) 2005). Notable in this regard are the levels of adoption and creation of technological innovation (Grupp and Mogeec 2004; Niosi 2010) and technological learning (Koh and Wong 2005; Organization for Economic Cooperation and Development (OECD) 2005) in creating this expansion.

A country's economic growth progresses through three stages of technological change and productivity, namely factor-driven growth, investment-driven growth, and innovation-driven growth (Koh and Wong 2005; Rostow 1959; World Economic Forum (WEF) 2012). Factor-driven economies produce goods based on natural endowments and low labor cost; investment-driven economies accumulate capital (technological, physical and human) and offer investment incentives; and innovation-driven economies emphasize research and development (R\&D),

(c) The Author(s). 2019 Open Access This article is distributed under the terms of the Creative Commons Attribution 4.0 International License (http://creativecommons.org/licenses/by/4.0/), which permits unrestricted use, distribution, and reproduction in any medium, provided you give appropriate credit to the original author(s) and the source, provide a link to the Creative Commons license, and indicate if changes were made. 
entrepreneurship, and innovation. Progressing from one growth stage to another involves transitioning from a technology-importing economy that relies on endowments, capital accumulation, infrastructure, and technology imitation, to a technology-generating economy that focuses on creating new products or knowledge using state of the art technology (Akcali and Sismanoglu 2015). In the creation of new products or knowledge, economies use a systemic approach to represent the interaction of public and private institutions with policies, incentives, and initiatives (Organization for Economic Cooperation and Development (OECD) 1997). Institutions include research entities, public laboratories, innovative enterprises, venture capital firms, and organizations that finance, regulate, and enable the production of science and technology (Malerba 2004; Mazzoleni and Nelson 2007; Niosi 2010). The government also plays a key role in supporting these institutions through policies, targeted incentives, $R \& D$ collaboration, and coordinated infrastructure.

According to the Oslo manual (Organization for Economic Cooperation and Development (OECD) 2005), innovation has been defined as the implementation of a new or significantly improved product/service, process, marketing method, or organizational method in business practices, workplace organization, or external relations. Though many innovation studies use variations of this definition, the common thread is Schumpeter (2008). Schumpeter proposes that the crux of capitalism lies in production for the mass market through creative destruction, that is, the continuous process of generating new products, processes, markets, and organizational forms that make existing ones obsolete (Lee 2015). In today's digital era, technology is integral to advancing such creative destruction. It is no surprise that innovation vis-à-vis technological innovation drives economic growth.

Technological innovation is measured using science and technology (S\&T) indicators. These indicators include resources devoted to R\&D, patents, technology balance of payments, and international trade in R\&D-intensive industries. The importance given to $\mathrm{S} \& \mathrm{~T}$ indicators increased with the call for a comprehensive analysis of the economy that not only incorporates economic indicators, but also those that represent knowledge creation (Lepori et al. 2008). However, for S\&T to translate to improved economic development (represented by improved quality of life, as well as wealth and employment creation), it needs to be geared towards bringing new products/processes into the marketplace-that is, towards innovation (Siyanbola et al. 2016). Attaining national development goals requires evidence-based and informed policy-making. Incorporating S\&T indicators offers the scientific evidence needed to effectively design, formulate, and implement national innovation policies that contribute to economic development. We base our study on this premise and utilize the S\&T indicators of R\&D, patents, and exports to explore country-level technological innovation for policy analysis. We offer research-based suggestions for governments to compare innovation policy initiatives, seek insights into solving national development problems, identify outstanding best practices, and work collaboratively. The rest of the paper is organized as follows: section 2 describes the research background; section 3 covers methodology; section 4 discusses the analyses results and discussion; section 5 offers scope and limitations; section 6 covers contributions and implications for future research; and section 7 presents the conclusions of our research. 


\section{Research background}

There are several theoretical models that offer rationales for technological innovation. The technology gap model developed by Posner (1961) explains how countries that are technologically advanced introduce new products into a market and enjoy the innovative advantage (Krugman 1986). However, this comparative advantage is transient and shifts over time to other countries that show sustained innovative activities due to technological improvements. The product life cycle hypothesis shows that industrialized countries with a high degree of human capital and R\&D investment produce more technical innovations and new products (Maksimovic and Phillips 2008). These countries enjoy the comparative advantage early in the product's life cycle. But as the country exports and the product becomes more standardized, it allows other countries to reproduce at a lower cost (with advanced technology) and gain market share. The endogenous growth model shows that technology, knowledge, and human capital are endogenous and primary contributors to innovation and economic growth (Gocer et al. 2016). It is clear that technological innovation offers a country a competitive edge that contributes to economic development and growth (Gocer et al. 2016). Therefore, measuring this phenomenon takes on increasing significance at national and global levels. We now describe our research framework and conceptualization of the innovation phenomenon.

\section{Research framework for innovation}

In this research, we adapt the comprehensive framework presented at the OECD workshop for national innovation capability using S\&T indicators (Qiquan et al. 2006).

According to Miles and Huberman (1994), a conceptual framework explains either graphically or in narrative form the main things to be studied-the key factors, concepts, or variables-and the presumed relationships among them. Using this definition, we have laid out the key concepts in our research and how they relate to the overall phenomenon of innovation.

We conceptualize innovation using the three components of inputs, knowledge creation and absorption, and outputs. Inputs to innovation are represented by efforts at research and development, including the expenditure and personnel hired for R\&D. Knowledge creation and absorption represents national efforts at motivating and rewarding the innovative process. The outputs of innovation represent exports of products and services. Figure 1 shows the research framework.

\section{Inputs- $R \& D$ expenditure and $R \& D$ personnel}

$R \& D$ is an important input to national innovation. It includes creative work undertaken systematically to increase the stock and the use of knowledge to devise new applications-both of which have the potential to influence innovation. RED expenditure is often used to encourage innovation and provide a stimulus to national competitiveness. Research has used R\&D expenditure as a percentage of GDP (referred to as R\&D intensity) to explain the relationship between firm size and innovative effort (Cohen 2010) and as an input to innovation (Kemp and Pearson 2007). In general, developed countries have higher R\&D intensity than developing countries.

For a country, the gross domestic expenditure on R\&D (GERD), which represents the expenditure on scientific research and experimental development, offers an indication 


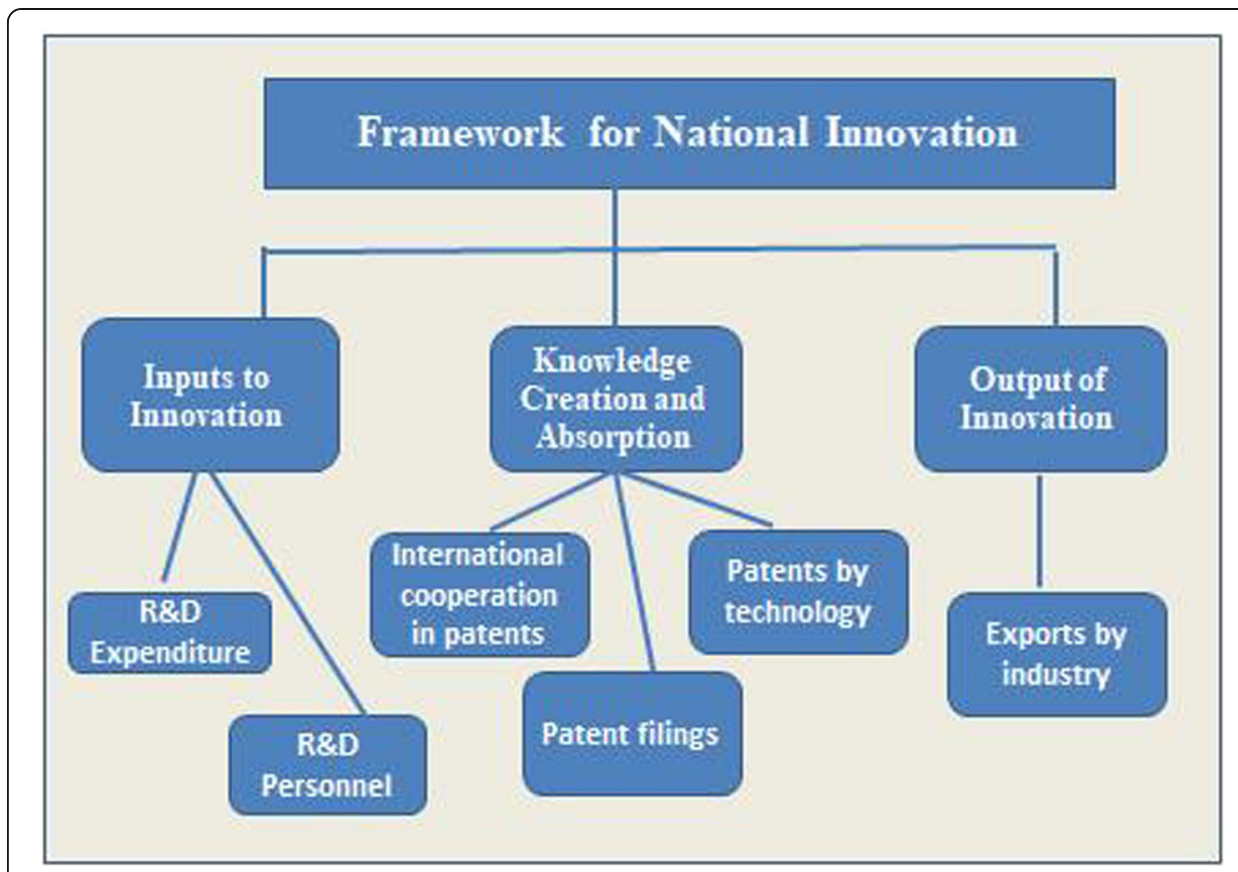

Fig. 1 Framework for national innovation

of the allocation of financial resources to R\&D in terms of the share in the GDP. Sufficient $R \& D$ funding is essential for innovation, economic growth, and sustainable development. Changes in $R \& D$ expenditure suggest evolving long-term strategies and policies related to innovation for economic development. GERD can be broken down among the performance sectors of business enterprise, government, higher education, and private not-for-profit institutions serving households.

Business enterprise expenditure on R\&D (BERD) is an important indicator of business commitment to innovation. Although not all business investments yield positive results, efforts towards R\&D signal a commitment to the generation and application of new ideas that lead to new or improved products/services for innovation. Research suggests that R\&D spending is associated with productivity and GDP growth. An increase of $0.1 \%$ point in a nation's BERD to GDP ratio could eventually translate to a $1.2 \%$ increase in GDP per capita (Expert Panel on Business Innovation 2009). Also, over the last few years, R\&D intensity in the business sector has varied considerably between countries (Falk 2006). It is, therefore, useful to analyze this at a global level.

The government intramural expenditure on R\&D (GOVERD) represents efforts by the government to invest in R\&D. Several motivations have been proposed for the same. Endogenous theories present such investment to be the foundation for economic growth (Griliches 1980). Governments respond to market failures in which firms under-invest due to the risk of externalities and information issues (Arrow 1962). Additionally, government funding can stimulate corporate R\&D activities (Audretsch et al. 2002; Görg and Strobl 2007). The average government-funded R\&D expenditure in 24 OECD countries doubled in three decades, from $\$ 6.04$ billion in 1981 to $\$ 12.3$ billion in 2008 (in US dollars, constant prices) (Kim 2014).

Higher education expenditure on R\&D (HERD) has been the focus of much research since the 1980s. Research has studied the transfer of knowledge and technology 
between the university and industry, using firm- or industry-level data (Adams et al. 2001; Collins and Wakoh 2000; Furman and MacGarvie 2007; Grady and Pratt 2000; Siegel et al. 2001). Since the 1990s, higher education institutions have played an increasingly important role in regional and national development in OECD countries, owing to the growth of strategic alliances across industry, research institutions, and knowledge intensive business services (Eid 2012). There is growing recognition that R\&D in higher education institutions is an important stimulus to economic growth and improved social outcomes. Funding for these institutions comes mainly from the government, but businesses, too, fund some activities (Eid 2012). Private, not-for-profit organizations are those that do not generate income, profits, or other financial gain. These include voluntary health organizations and private philanthropic foundations. Expenditure on R\&D represents the component of GERD incurred by units belonging to this sector.

In addition to expenditure, $R \& D$ personnel are an input to the innovation phenomenon in a country. RED personnel refer to all human capital including direct service personnel, such as managers, administrators, and clerical staff, who are involved in the creation of new knowledge, products, processes, and methods, and can be employed in the sectors of public, private, or academia.

\section{Knowledge creation and absorption-patents}

In the innovation framework, knowledge creation is the process of coming up with new ideas through formal R\&D (Organization for Economic Cooperation and Development (OECD) 2005). Knowledge absorption is the process of acquiring and utilizing knowledge from entities such as universities, public research organizations, or domestic and international firms (Organization for Economic Cooperation and Development (OECD) 2005). Factors influencing knowledge absorption include human capital, R\&D, and linkages with external knowledge sources. On a national level, the creation and absorption of knowledge is manifested through the evolution of intellectual property (IP).

Countries institute regulatory frameworks in the form of patents and copyrights, to protect intellectual property and innovation (Blind et al. 2004). The rationale for protection arises from the fact that innovation amounts to knowledge production, which is inherently non-rival and non-excludable. Non-rival refers to the notion that the amount of knowledge does not decrease when used by others, and non-excludable refers to the unlimited ability of others to use and benefit from the knowledge once it is produced. Countries, therefore, institute legal systems to protect the rights of inventors and patent holders. An example is the Bayl-Dohl Act in the USA. By calibrating the strength of patent protection rights, policymakers can influence national innovation systems (Raghupathi and Raghupathi 2017). Legal protection and exclusivity of the use of knowledge allows investment in R\&D and leads to the production of knowledge and innovation. Research in the area of patents has often centered on whether stronger IP rights lead to more innovation (Hall 2007; Hu and Jaffe 2007; Jaffe 2000) and on the endogeneity of patent rights on industries (Chen 2008; Moser 2005; Qian 2007; Sakakibara and Branstetter 2001). As patent rights change at a national level, industries within a country may react differently according to the importance of such rights to the respective industries (Rajan and Zingales 1998). Exploring patent applications or distribution by industry 
is therefore a key estimator of the extent of national innovation (Qian 2007). Patent laws have a significant effect on the direction of technological innovation in terms of which industries have more innovations (Moser 2005). In addition to using individual patent applications as a measure of patent activity, national innovation research also uses patent families, which are sets of patents/applications covering the same invention in one or more countries. These applications relate to each other by way of one or several common priority filings (Organisation for Economic Cooperation and Development OECD 2009). Patent families reflect the international diffusion of technology and represent an excellent measure of national innovativeness (Dechezlepre^tre et al. 2017).

In the current research, in contrast to studies that look at domestic patent families in an American (Hegde et al. 2009) or European context (Gambardella et al. 2008; Harhoff 2009; van Zeebroeck and van Pottelsberghe 2011), we adopt a global approach and consider patent families in all three major patent systems: the United States Patent and Trademark Office, the European Patent Office, and the Japan Patent Office. This examination allows us to identify possible international patent-based indicators that enable rigorous cross-country comparisons of innovation performances at national and sectoral levels.

\section{Outputs-exports}

Exports represent an output of the innovative activity of a country. Endogenous growth models suggest that firms must innovate to meet stronger competition in foreign markets (Aghion and Howitt 1998; Grossman and Helpman 1991; Hobday 1995). Firms enhance their productivity prior to exporting in order to reach an optimum level that qualifies them to compete in foreign markets (Grossman and Helpman 1995). Upon entry into the export market, continued exposure to foreign technology and knowledge endows a "learning-by-exporting" effect that offers economies of scale that further enable covering the cost of R\&D (Harris and Moffat 2012).

In the context of our research framework, we explore the following research questions using a descriptive visualization and an econometric panel regression approach:

How do the SET indicators (RED expenditure, patents, and exports) influence countrylevel innovation?

How do countries around the world differ in terms of innovation with SET indicators?

\section{Research methodology}

We now discuss our methodology in studying science and technology indicators for national innovation. Table 1 summarizes the research methodology.

\section{Data collection and variable selection}

We downloaded innovation data from the Master Science and Technology Indicator (MSTI) database of the Organization for Economic Cooperation and Development (OECD), for the years 2000 to 2016 (https://stats.oecd.org). The MSTI database contains indicators that reflect efforts towards science and technology of 
Table 1 Research methodology

Data collection
Data source: https://stats.oecd.org/
Years: 2000-2016
Variable selection
Science and technology indicators (MSTI database)
Research \& development—R\&D expenditure; R\&D personnel
Patents—international cooperation in technology; patent filing; patent by technology
Exports—exports by industry
Analytics platform/tools selection
Tableau and R
Analytics implementation
Visualization-Tableau
Panel analysis—R

OECD member countries and non-member countries. The data covers provisional or final results, as well as forecasts from public authorities. MSTI indicators include, among others, resources dedicated to research and development, patent (including patent families), and international trade in $R \& D$ intensive industries. Table 2 shows the variables in the research.

Research and development variables include gross domestic expenditure on R\&D (GERD) for the sectors of business enterprise, higher education, government, and private/non-profit households; funding sources include industry, government, abroad, and other national sources. For business enterprise, we included the industries of aerospace, computer/electronic/optical, and pharmaceutical. We also look at R\&D personnel as a percentage of the national total in the abovementioned business sectors. In patents, we consider indicators such as the number of triadic patent families, which includes patents filed at the offices of the European Patent Office, the United States Patent and Trademark Office, and the Japan Patent Office, for the same invention by the same applicant or inventor. Patent variables also include those representing the international flow of patents and cross-border ownerships in the inventive process. Patents are considered for the technology sectors of biotechnology, information and communication technology (ICT), environmental technology, and pharmaceutical. As exports represent the outputs of the innovative process, we consider total exports in the three industries of aerospace, computer/electronic/optical, and pharmaceutical.

We use panel data that includes variables for multiple indicators spanning multiple countries and time period. There are several ways to group country-level data. We use the income-level classification of the World Bank of high, upper-middle, lower-middle, and low income. However, due to the lack of availability of data, we only focus on upper-middle and high-income categories. In addition, we use the region classification of East Asia and Pacific, Europe and Central Asia, Latin America and the Caribbean, Middle East and North Africa, North America, South Asia, and Sub-Saharan Africa. 
Table 2 Variables in the research

\begin{tabular}{|c|c|c|}
\hline Category & Variable & Description \\
\hline \multicolumn{3}{|c|}{ Research and development } \\
\hline \multirow[t]{7}{*}{ R\&D expenditure } & BERD (\%) & Business enterprise expenditure on R\&D (BERD) as a \% of GDP \\
\hline & $\begin{array}{l}\text { BERD by industry } \\
\text { (current PPP dollars \$) }\end{array}$ & $\begin{array}{l}\text { Business enterprise expenditure on R\&D (BERD) performed in the } \\
\text { industries of service, aerospace, computer, electronic and optical, } \\
\text { pharmaceutical, }\end{array}$ \\
\hline & GERD (\%) & Gross domestic expenditure on R\&D as a \% of GDP \\
\hline & $\begin{array}{l}\text { GERD by sector of } \\
\text { performance }\end{array}$ & $\begin{array}{l}\text { GERD in the sectors of: business enterprise } \\
\text { (GERD_BUS_PERFORM), government (GERD_GOV_PERFORM), } \\
\text { higher education (GERD_HIGH_PERFORM), and private sector } \\
\text { (GERD_PRIVATE_PERFORM) }\end{array}$ \\
\hline & $\begin{array}{l}\text { GERD by source of } \\
\text { funds }\end{array}$ & $\begin{array}{l}\text { GERD financed by other national sources, government } \\
\text { (GERD_GOV_FINANCE), industry (GERD_IND_FINANCE), and } \\
\text { abroad (GERD_ABROAD_FINANCE) }\end{array}$ \\
\hline & GOVERD & $\begin{array}{l}\text { Government intramural expenditure on R\&D (GOVERD) as a \% } \\
\text { of GDP }\end{array}$ \\
\hline & HERD & Higher education expenditure on R\&D as a \% of GDP \\
\hline \multirow[t]{3}{*}{ R\&D personnel } & GOVER_RESEARCHER & Government researchers as a \% of national total \\
\hline & BUS_RESEARCHER & Business enterprise researchers as a \% of national total \\
\hline & HIGH_RESEARCHER & Higher education researchers as a \% of national total \\
\hline \multicolumn{3}{|l|}{ Patents } \\
\hline \multirow[t]{3}{*}{ Patent filing } & PATENT_TRIADIC & $\begin{array}{l}\text { Number of "triadic" patent families (priority year), based on } \\
\text { inventor(s)'s countries of residence }\end{array}$ \\
\hline & PATENT_PCT & $\begin{array}{l}\text { Number of patent applications filed under the PCT(priority year), } \\
\text { based on inventor(s)'s countries of residence }\end{array}$ \\
\hline & PATENT_EPO & $\begin{array}{l}\text { Number of patent applications filed under the European Patent } \\
\text { Office (priority year), based on inventor(s)'s countries of residence }\end{array}$ \\
\hline \multirow{3}{*}{$\begin{array}{l}\text { International } \\
\text { cooperation } \\
\text { in patents }\end{array}$} & COOP_COINVENTOR\% & $\begin{array}{l}\text { The total percentage of patents invented with foreign } \\
\text { co-inventors under EPO where reference date is prior date. }\end{array}$ \\
\hline & COOP_OWN\% & $\begin{array}{l}\text { The total percentage of patents owned by foreign residents in } \\
\text { EPO where reference date is prior date. }\end{array}$ \\
\hline & COOP_ABROAD\% & $\begin{array}{l}\text { The total percentage of patents invented abroad in EPO where } \\
\text { reference date is Prior Date. }\end{array}$ \\
\hline \multirow[t]{4}{*}{$\begin{array}{l}\text { Patents by } \\
\text { technology }\end{array}$} & PATENT_BIO & $\begin{array}{l}\text { Number of patents in the biotechnology sector - applications } \\
\text { filed under the PCT (priority year), based on inventor(s)'s } \\
\text { countries of residence }\end{array}$ \\
\hline & PATENT_ICT & $\begin{array}{l}\text { Number of patents in the ICT sector-applications filed under } \\
\text { the PCT, based on inventor(s)'s countries of residence } \\
\text { (priority year) }\end{array}$ \\
\hline & PATENT_ENV & $\begin{array}{l}\text { Number of patents in the ENV_TECH sector_applications filed } \\
\text { under the PCT, based on inventor(s)'s countries of residence } \\
\text { (priority year) }\end{array}$ \\
\hline & PATENT_PHARMA & $\begin{array}{l}\text { Number of patents in the PHARMA sector-applications filed } \\
\text { under the PCT, based on inventor(s)'s countries of residence } \\
\text { (priority year) }\end{array}$ \\
\hline \multicolumn{3}{|l|}{ Exports } \\
\hline \multirow{3}{*}{$\begin{array}{l}\text { Export of particular } \\
\text { industries }\end{array}$} & EXPORT_AERO & Total exports: aerospace industry (current prices) \\
\hline & EXPORT_IT & $\begin{array}{l}\text { Total exports: computer, electronic, and optical industry } \\
\text { (current prices) }\end{array}$ \\
\hline & EXPORT_PHAR & Total exports: pharmaceutical industry (current prices) \\
\hline
\end{tabular}




\section{Analytics platform/tools selection}

For the data analysis, we use the platforms of Tableau, which is an advanced business intelligence and data mining tool, for visualization and descriptive analysis, and R for the panel regression analysis.

\section{Analytics implementation}

We use the visualization tools in Tableau to analyze and get insight from the innovation data. The goal of visualization is to analyze, explore, discover, illustrate, and communicate information. In today's digital era, users are overwhelmed with myriad information. Visualization provides models of the information (Khan and Khan 2011; North 2005) and makes intelligible huge amounts of complex information. The visual analytics capabilities of the business intelligence software, Tableau, represent data graphically, filter out what is not relevant, drill down into lower levels of detail, and highlight subsets of data across multiple graphs-and do all these simultaneously. This level of customization results in insights unmatched by traditional approaches. Static graphs delivered on paper or electronically via computer screen help communicate information in a clear and enlightening way, an enormous benefit. But users derive the greatest benefits from Tableau's visual analytics. Visual representation allows one to identify patterns that would otherwise be buried in vast, unconnected datasets. Unlike the traditional hypothesis-and-test method of inquiry, which relies on asking the right questions, data visualizations bring themes and ideas to the surface without pre-conceived assumptions and where they can be easily discerned. In the current context of international or global data, we integrate and display dimensions of information that are needed to rapidly monitor aspects of global innovation on interactive dashboards. In this way, we discover patterns and seek relationships in various areas of innovation inquiry for policymaking and national development. In addition to visualization approach to analysis, we also deploy the econometric panel regression analysis. Our research contains panel data of observations of multiple phenomena obtained over multiple time periods for different regions. Using panel analysis allows us to address analytical questions that regular cross-sectional or longitudinal analysis cannot. In addition, it provides for means to handle missing data; failing which, problems such as correlation of omitted variables with explanatory variables can undermine the accuracy of the effects.

\section{Results and discussion}

We discuss the results of our analysis and offer a comprehensive summary for each component in the research. We first discuss the visualization approach and then the panel analysis approach.

\section{Visualization and descriptive analytics}

\section{Research and development expenditure}

Expenditure on R\&D encompasses gross domestic expenditure (GERD), business enterprise expenditure (BERD), government intramural expenditure (GOVERD), and higher education expenditure (HERD). We analyze the distribution of GERD by country (Fig. 2). 


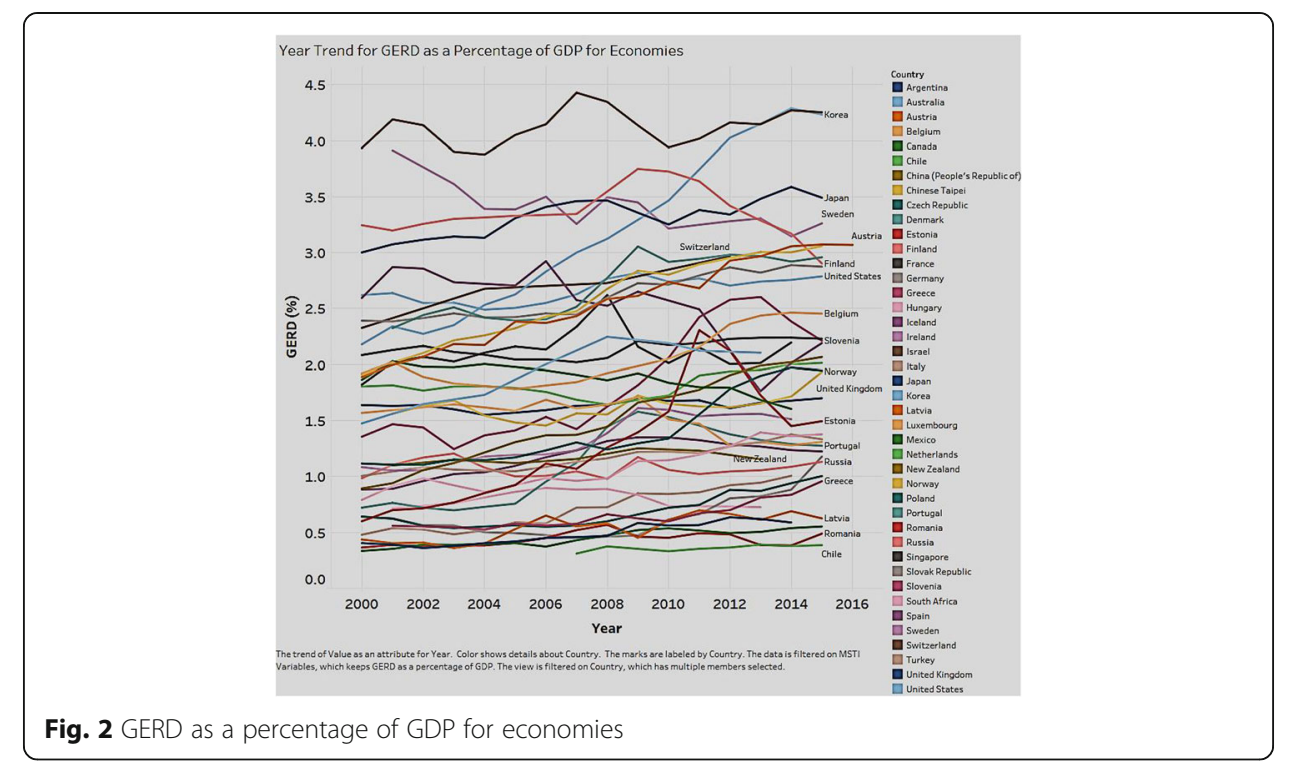

As seen in Fig. 2, there are variations between countries in the expenditure on R\&D. Some countries take the lead in GERD. For example, Israel takes the lead in GERD, with $25 \%$ more than the expenditure of Japan, double that of China, and quadruple that of Chile. Others include South Korea, Finland, Austria, Denmark, Chinese Taipei, and the USA. In terms of the trend of expenditure, there are countries that show a spiked increase over the years-South Korea shows an increase from 2.18 to $4.23 \%$ from 2000 to 2015; China from $0.885 \%$ in 2000 to $2.067 \%$ in 2015 ; and Denmark from 2.32 to 2.95\% between the years 2001 and 2015. Some countries show a consistent range of $R \& D$ expenditure for this same time span. The USA, for example, shows between 2.62 and $2.79 \%$ for the period 2000 to 2015 . Mexico shows a minimal change from 0.33 to $0.49 \%$ between the years 2000 and 2015. In terms of R\&D intensity, countries like Chile, Mexico, and Romania show a consistently low rate (between 0.2 and $0.4 \%$ ), while

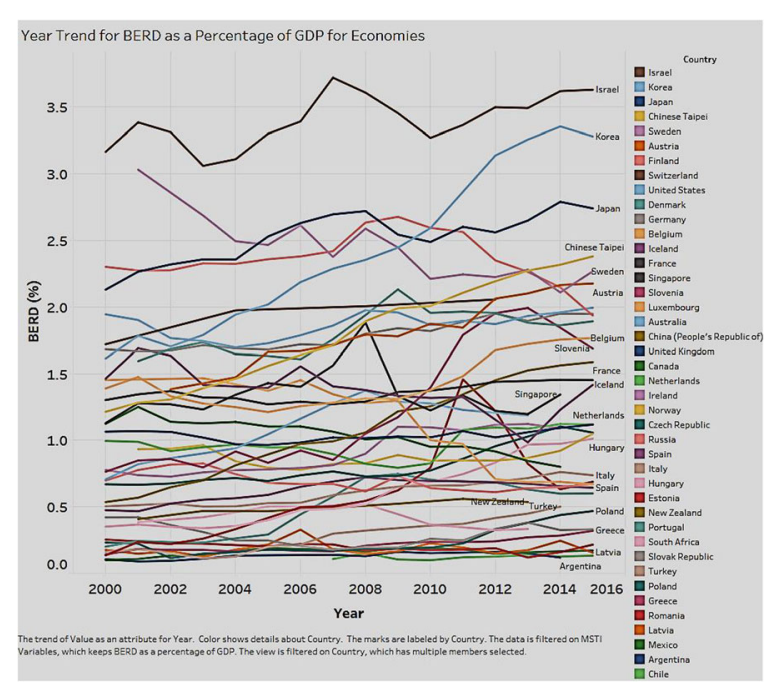

Fig. 3 Business enterprise expenditure on R\&D (BERD) 
others like Canada actually show a decrease over the years $(1.865 \%$ in 2000 to $1.605 \%$ in 2014). A country's increase in expenditure on R\&D reflects a dedicated effort towards national innovation.

We analyze the distribution of the expenditure for each of the performance sectors of business, government, and higher education. Figure 3 shows the distribution of business enterprise expenditure on R\&D (BERD) as a percentage of GDP among countries.

BERD encompasses all R\&D activities performed by enterprises and is normalized to account for the size of the country. As seen in Fig. 3, most countries show an increasing trend in BERD for the years 2000 to 2015. Israel takes the lead in BERD, followed by South Korea and Japan. Chile, Romania, and Latvia have the lowest expenditure. The distribution of government intramural expenditure on R\&D (GOVERD) is shown in Fig. 4.

As Fig. 4 shows, most countries show a decreasing trend in government expenditure on R\&D for the years 2000 to 2015 . Iceland shows a large drop, from $0.66 \%$ in 2000 to $0.11 \%$ in 2010 . Chinese Taipei also shows a decrease, from a relatively high $0.55 \%$ in 2003 to $0.38 \%$ in 2015. Other countries with a relatively low share of GOVERD also demonstrate a decreasing trend over these years. For example, Denmark shows a fall from 0.27 to $0.07 \%$ in 2015 . In general, we see that government expenditure on R\&D takes a decreasing pattern over time. A possible explanation is that research carries a degree of uncertainty and risk, initially keeping businesses and private investors at bay and forcing the government to step in to fill this void and encourage innovation (Walwyn and Cloete 2016). The implications will be discussed in detail in the "Conclusions" section. Figure 5 shows the distribution of higher education expenditure (HERD).

As Fig. 5 illustrates, a majority of countries show an increase over the years. Denmark, in particular, shows a large increase, from $0.44 \%$ in 2000 to $0.99 \%$ in 2015 . Sweden, Switzerland, Portugal, and the Czech Republic show similar increases. A few countries demonstrate a decrease; Hungary is one of them $(0.25 \%$ in 2003 to $0.17 \%$ in 2015). For the most part, emphasis among countries on HERD is a promising trend. It reflects increasing awareness that $R \& D$ in higher education institutions offers integral

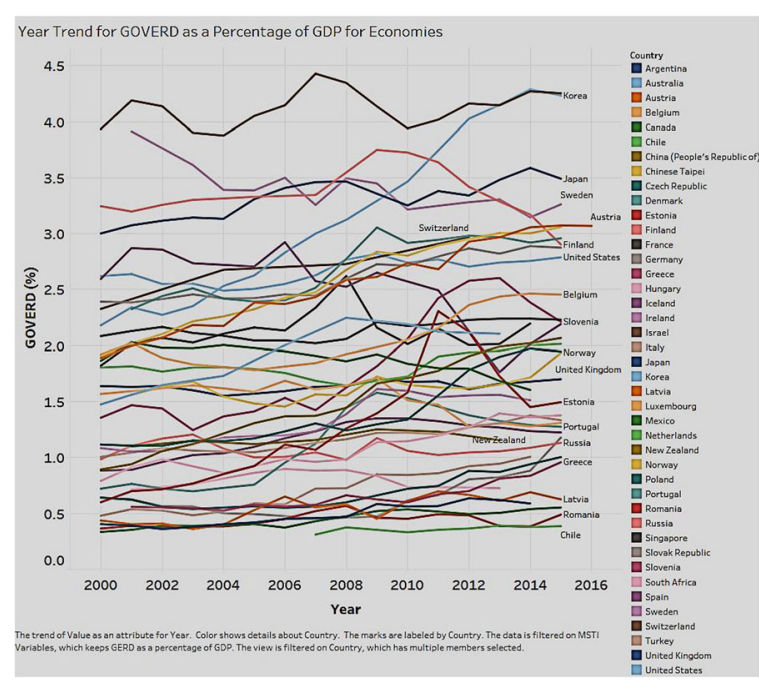

Fig. 4 Government intramural expenditure on research and development (GOVERD) 


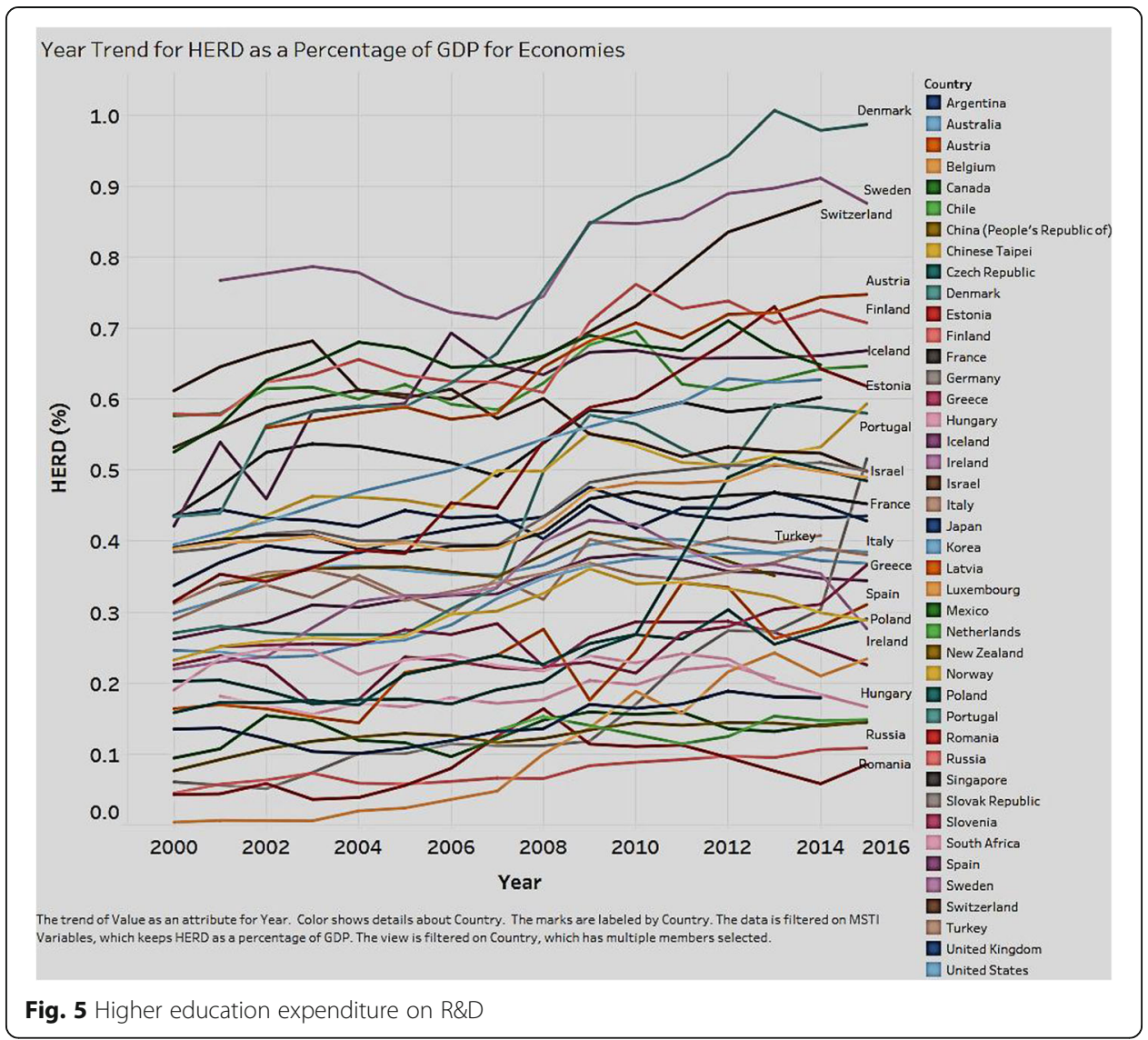

stimulus to economic growth and innovation. It follows that most higher education institutions receive their funding from national governments and businesses (Eid 2012).

Using regional and income-level classifications, we looked for differences in the distribution of expenditure (GERD) in each of the performance sectors of business, government, and higher education. Figure 6 shows the sectoral distribution by region.

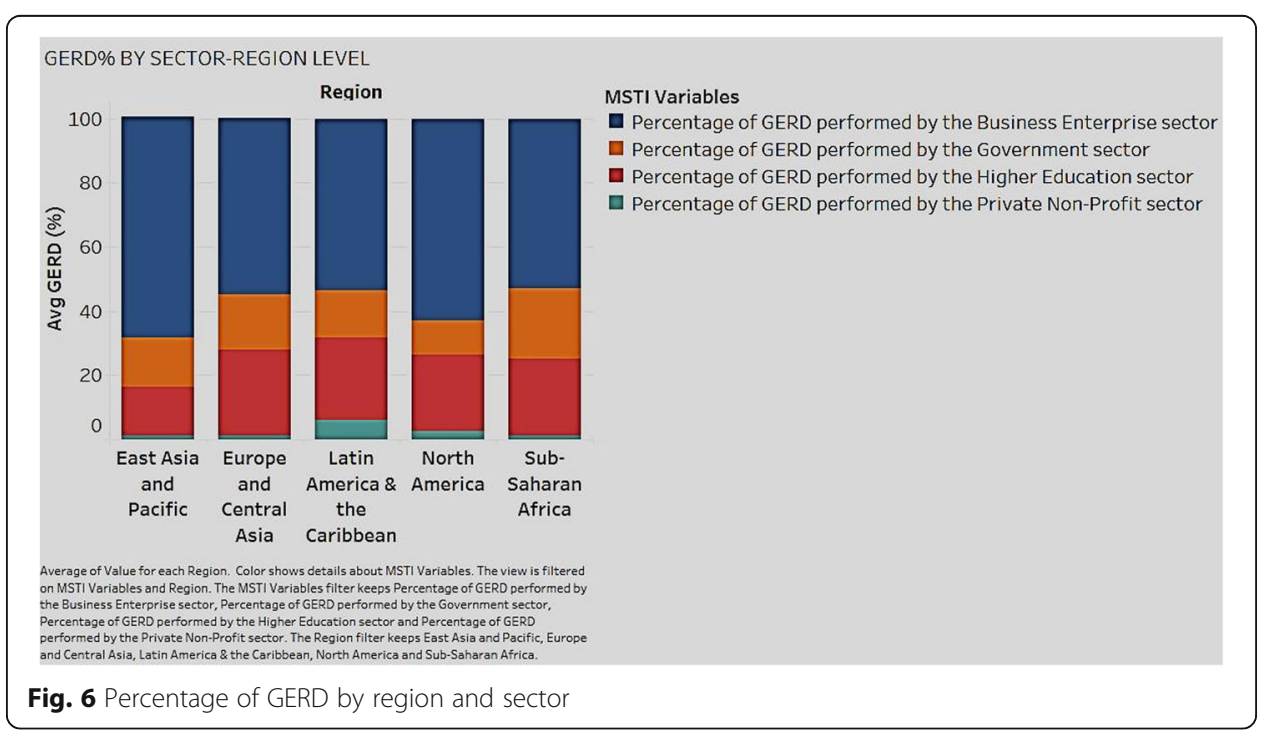




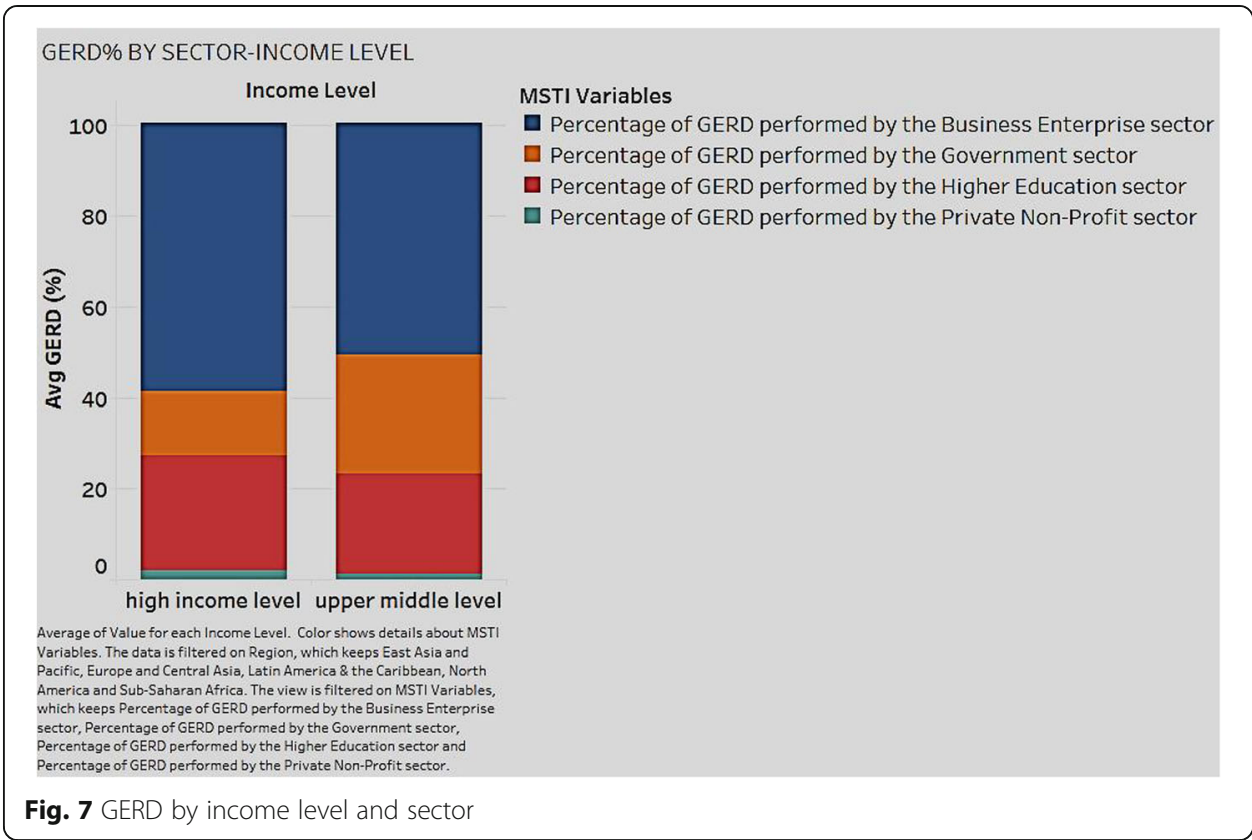

Figure 6 shows that for all regions, the business sector shows the highest expenditure, followed by the education and government sectors. The private non-profit shows the lowest expenditure. In Europe and Central Asia, there is a greater proportion of expenditure from the higher education sector than the government sector. In terms of government expenditure on $\mathrm{R} \& \mathrm{D}$, the Sub-Saharan region shows the highest spending, while the region of North America shows the lowest. We then mapped the sectoral distribution by income level (Fig. 7).

In both the high- and upper-middle-income countries, the business sector has the highest expenditure on $R \& D$. This is followed by the higher education sector in the high-income countries and the government sector in the upper-middle-income countries. Expenditure on R\&D from the private, non-profit sector is negligible for both income

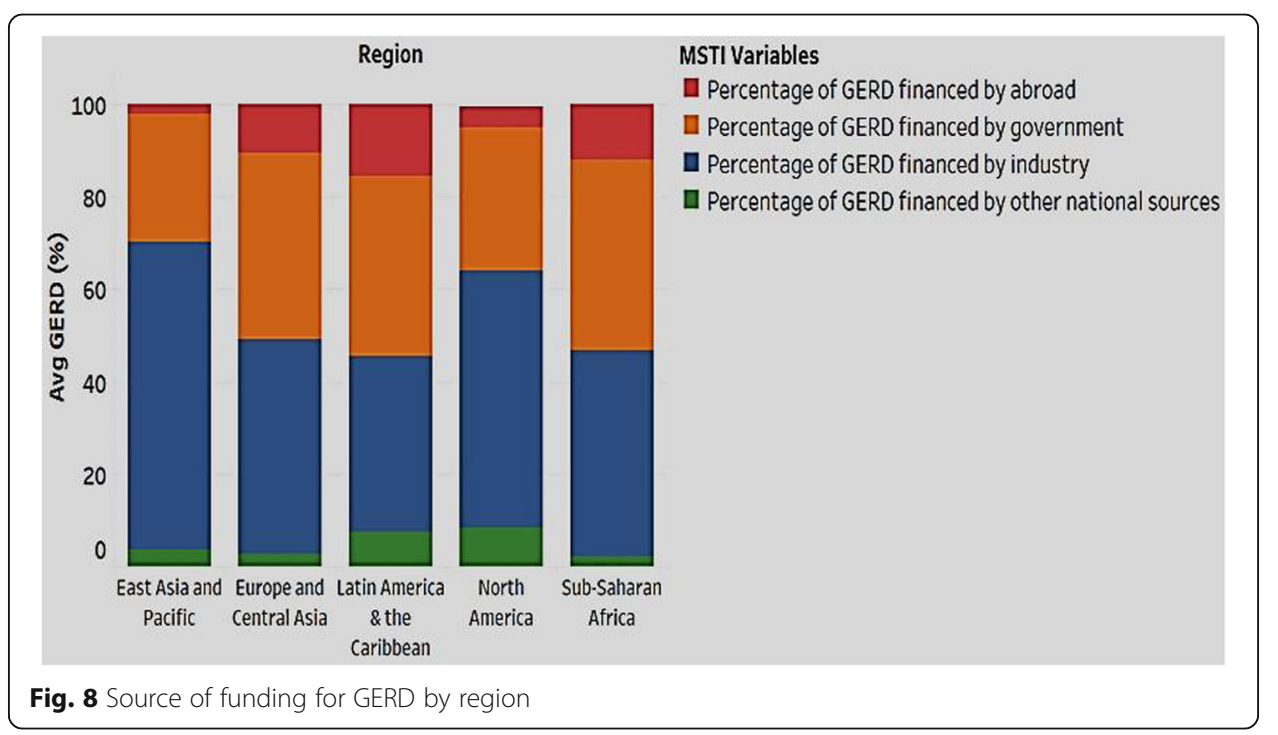


levels. It can be seen that the governments of high-income countries are less focused on spending on R\&D. The implication of this finding is discussed in our conclusions.

The source of funds for GERD is an important factor in analyzing the pattern of investments and expenditure for $R \& D$. We wanted to see if there were any identifiable patterns in country-level funding for R\&D. Figure 8 shows the source of funds for R\&D expenditure for regions around the world.

Figure 8 shows the expenditure financed by government, industry, and other national and foreign sources. Funding from abroad represents an important source for expenditure because $R \& D$ is an activity that entails significant transfer of resources between such entities as organizations and countries. Our analysis shows notable regional variation in the structure of funding. For instance, in East Asia and Pacific, industry accounts for funding more than three fifths of total GERD (66.51\%). However, it has a relatively low share of funding by government, national, and foreign sources. In the Sub-Saharan region, $44.54 \%$ of expenditure is funded by industry and an almost equal share is sourced by the government (41.31\%). It therefore follows that, contrary to our hypothesis, only the developed regions show more funding from the industry while the developing (upper middle income) regions show at best equal or more funding from the government.

Industries play a vital role in business $R \& D$ expenditure and are pivotal to improving the innovative landscape of a country. Figure 9 shows the distribution of BERD among regions for the industries of service, aerospace, computer/electronic/ optical, and pharmaceutical.

Figure 9 shows that in East Asia and Pacific, the highest expenditure is by the computer/electronic/optical industry; service follows. In Europe and Central Asia, expenditure in the year 2000 is equal across all four industries, but during later years, the service industry dominates expenditures. The distribution is different in Latin America and Caribbean, where more than 95\% of expenditure is concentrated on the service and computer industries over the span we are studying. In North

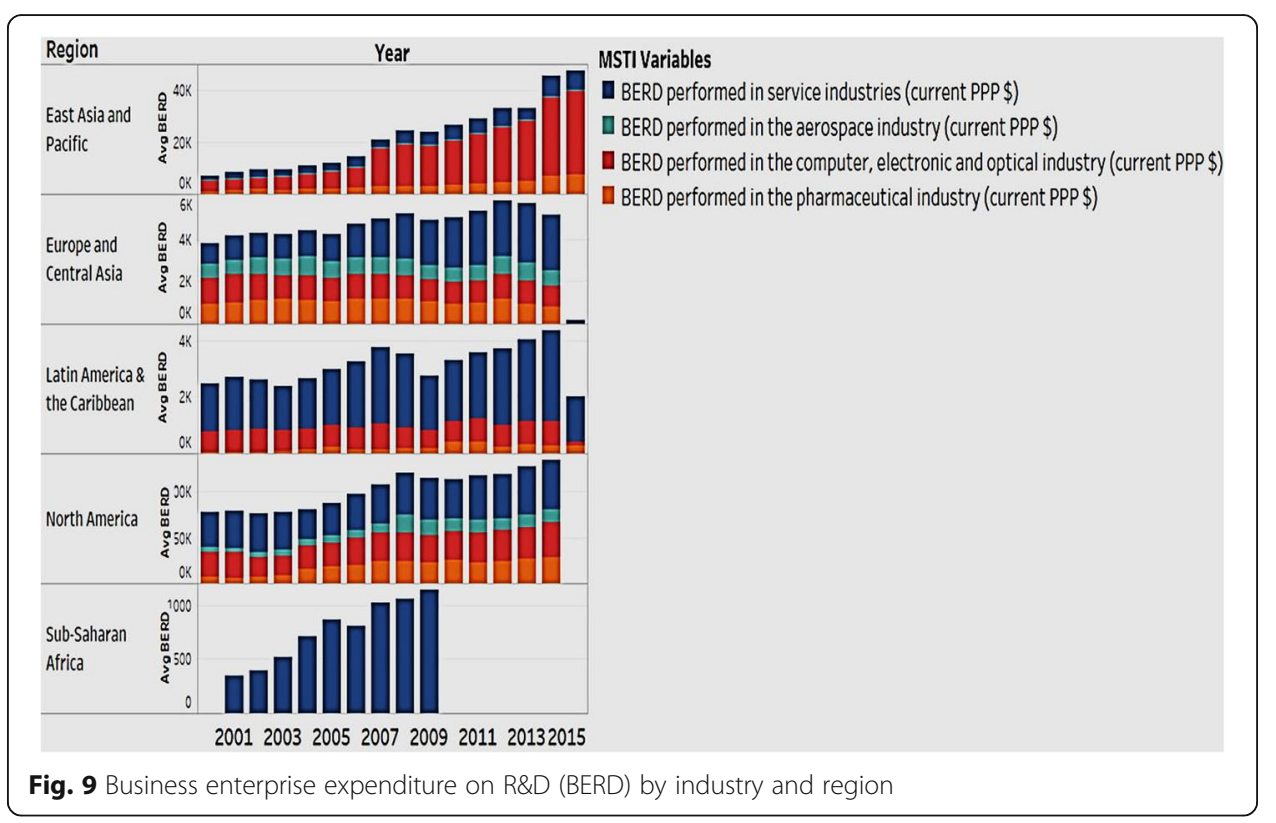


America, the service and computer industries dominate throughout the time span, with the aerospace industry taking the smallest share-less than $20 \%$. In the sub-Saharan region, the service industry plays a dominant role. Note that our analysis for this region is limited because data is missing for the years 2010 to 2015, but we chose to include in our analysis the data that is available in order to provide as holistic an outlook as possible. In general, it appears that developed regions focus more on the technology sectors while developing regions focus more on service sectors.

\section{$R \& D$ personnel}

We looked at the number of researchers engaged in each performance sector as a percentage of the national total. Regions and countries differ in the allocation of personnel in the different sectors of business, government, and higher education. In developing regions since the government invests more in $R \& D$ expenditure, we expected the same trend to reflect in personnel. Figure 10 shows the sectoral distribution of $R \& D$ personnel as a percentage of national totals for each region.

Figure 10 clearly displays structural variations in the regions for R\&D personnel. The regions of East Asia and Pacific, Europe and Central Asia, and North America reveal a steady business sector pattern, engaging the highest share of personnel; the government sector engages the lowest. In other regions, such as Latin America and the Caribbean, the education sector leads in personnel. The business sector is significant as it shows a steady annual increase. It appears that, in developed regions the business sector engages a higher share of $R \& D$ personnel than in developing regions. We now move on to analyze patents.

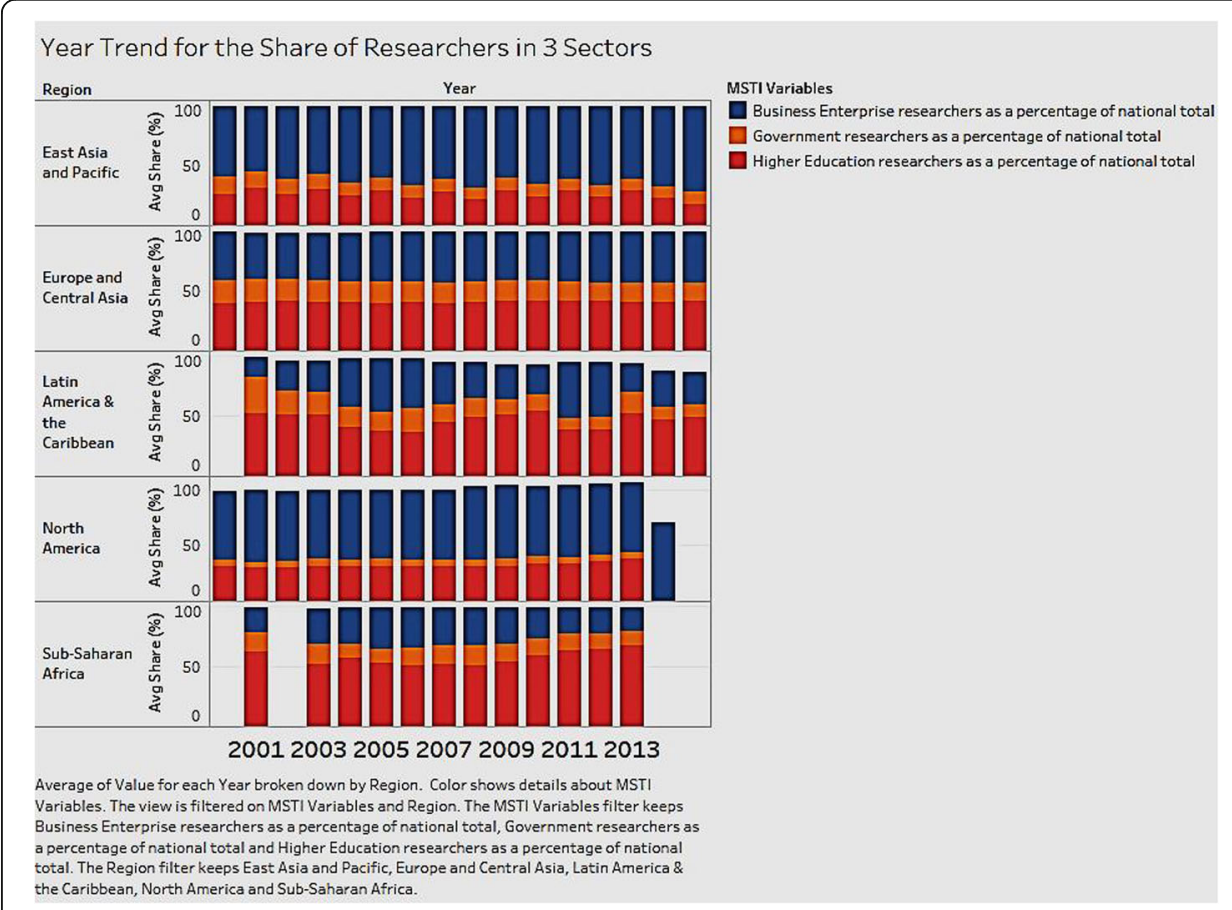

the Caribean, North America and Sub-Sahoran Africo.

Fig. $10 R \& D$ Personnel by region and sector 


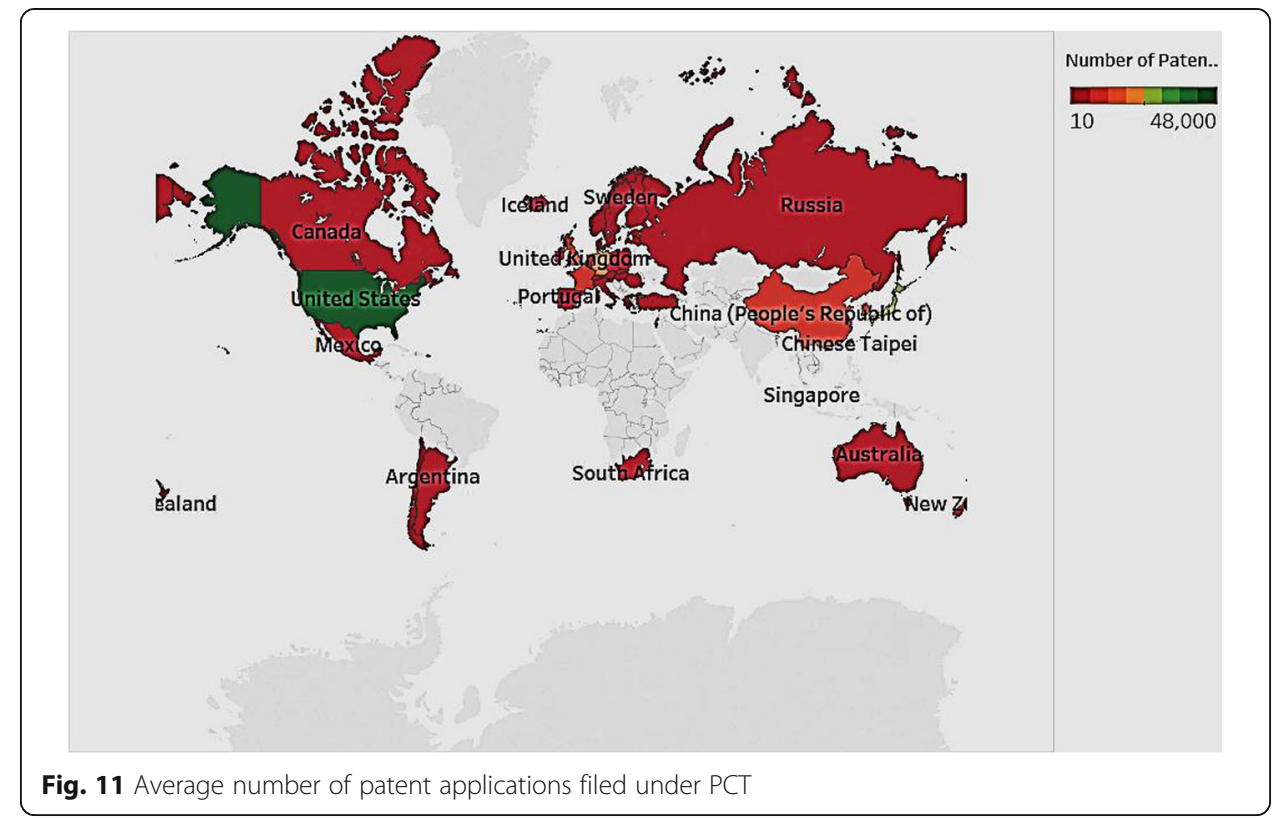

\section{Patents}

The average number of patent applications filed under the Patent Cooperation Treaty (PCT) reflects the extent of technological innovation in a country (Fig. 11). Figure 11 shows the patent applications filed under PCT for the years 2000 to 2016.

In the figure, green denotes a high number and red a low number of applications. The USA has the highest number of patent applications, followed by Japan and China. By comparison, Russia, Argentina, and other countries see a very low number of patent applications, signaling a need for innovative focus.

As for the number of patent applications filed under European Patent Office (EPO) (Fig. 12), the USA leads Japan, Germany, and France. We now turn to applications for triadic patent families (Fig. 13).

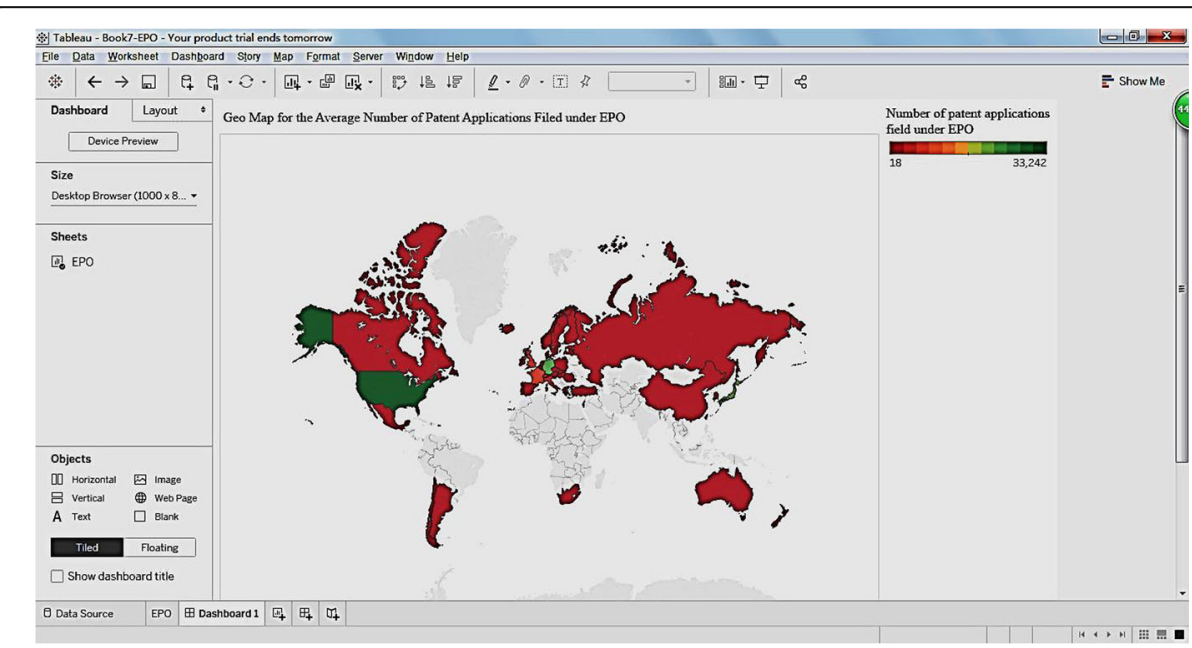

Fig. 12 Average number of patent applications filed under EPO 


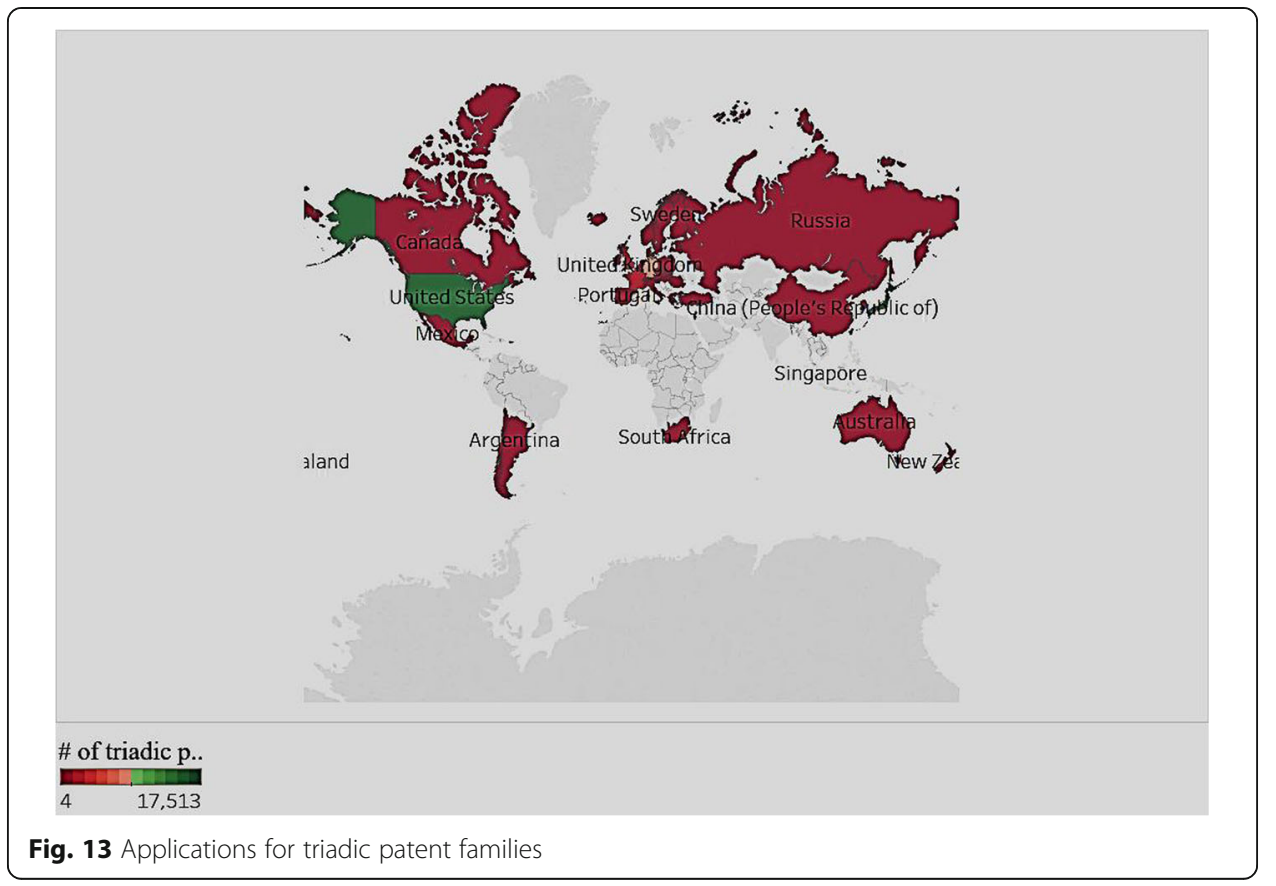

A triadic patent family is defined as a set of patents registered in patent offices of various countries to protect the same invention. The European Patent Office (EPO), the Japan Patent Office (JPO), and the United States Patent and Trademark Office (USPTO) are the three major patent offices worldwide. Counting triadic patent families begins with each inventor's country of residence and the initial date of registration of the patent. Indicators based on patent families normally enhance the international comparability and the quality of patent indicators. The greatest number of triadic patent families originated in the USA, followed by Japan, Germany, and France. In general, countries like the USA, Japan, Germany, and France are high in the number of patent filings under EPO and PCT.

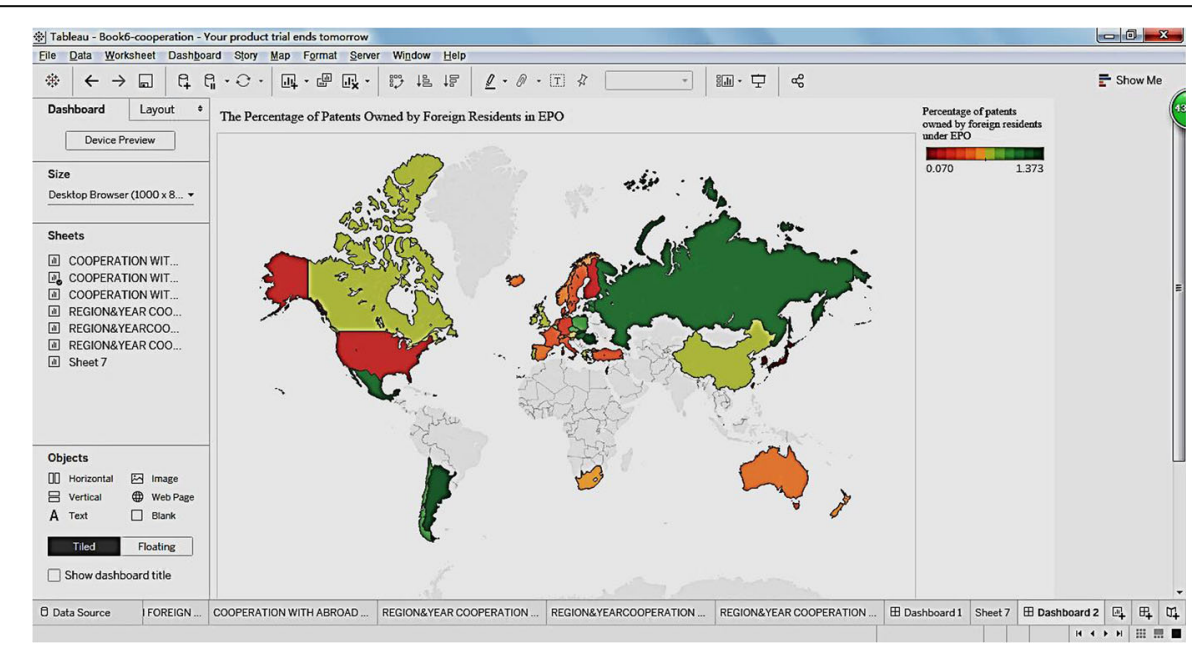

Fig. 14 Percentage of patents owned by foreign residents under EPO 
Co-inventions reflect international collaboration and represent the flow of information and knowledge across borders. They also indicate the flow of funds from multinational companies for R\&D. Figure 14 shows the analysis for the percentage of patents owned by foreign residents under EPO.

In Fig. 14, countries represented in green indicate a high percentage of ownership of patents with foreign residents; the darker the green, the higher the percentage. Countries in red indicate a low percentage of ownership. The US, Japan, and other EU economies have a relatively low share of patents owned by foreign residents, and most of the patent ownership in these countries is local. By contrast, countries like Argentina, Russia, and Mexico show a high percentage of patents owned by foreign residents. These countries rely on foreign collaboration to strengthen their resources and facilities for innovation (Raghupathi and Raghupathi 2017). This signals a need to strengthen local innovation by targeting education systems to offer relevant skills and knowledge that foster growth. The portfolio of ownership of patents between local and foreign residents is an interesting revelation that offers implications for national policies on taxation and innovation, and will be discussed further in our conclusions. In the analysis of the percentage of patents invented abroad (Fig. 15), the difference globally is not as varied as it is for patents owned by foreign residents (as shown earlier, in Fig. 14).

As Fig. 15 illustrates, the majority of countries in our study show less than $1 \%$ of patents are invented abroad. Only Switzerland (1.16\%) and Ireland (1.28\%) show relatively high levels.

We looked next at the differences in distribution of patents by sector. We considered the various technology domains of environmental technology, pharmaceutical, ICT, and biotechnology. Figure 16 shows the comparison of the number of patents in each technology domain to the benchmark of the total number of patent applications under PCT.

Environmental technology is the application of environmental science, green chemistry, environmental monitoring, and electronic technology to monitor and conserve the natural environment and resources and to mitigate the negative effects of humans on the environment. Sustainable development is the primary objective of environmental technology. Figure 16 shows the number of patents in the environmental technology sector and indicates a steady increase from 2000 to 2011 and a sudden decrease from

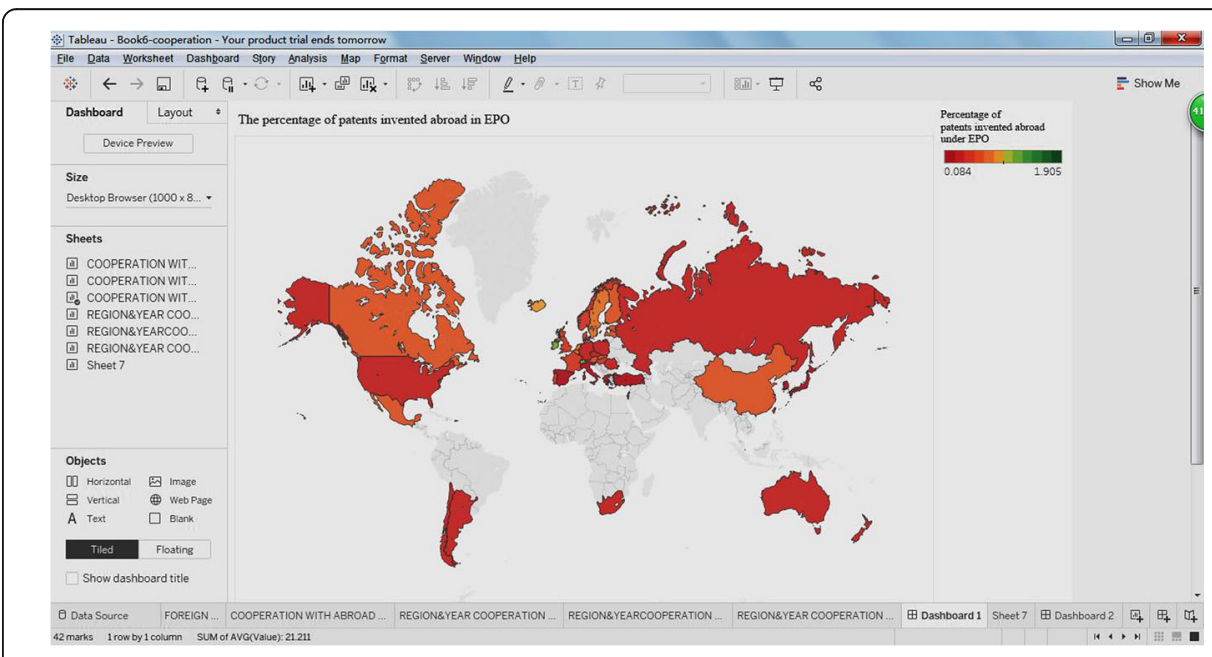

Fig. 15 Percentage of patents invented abroad under EPO 


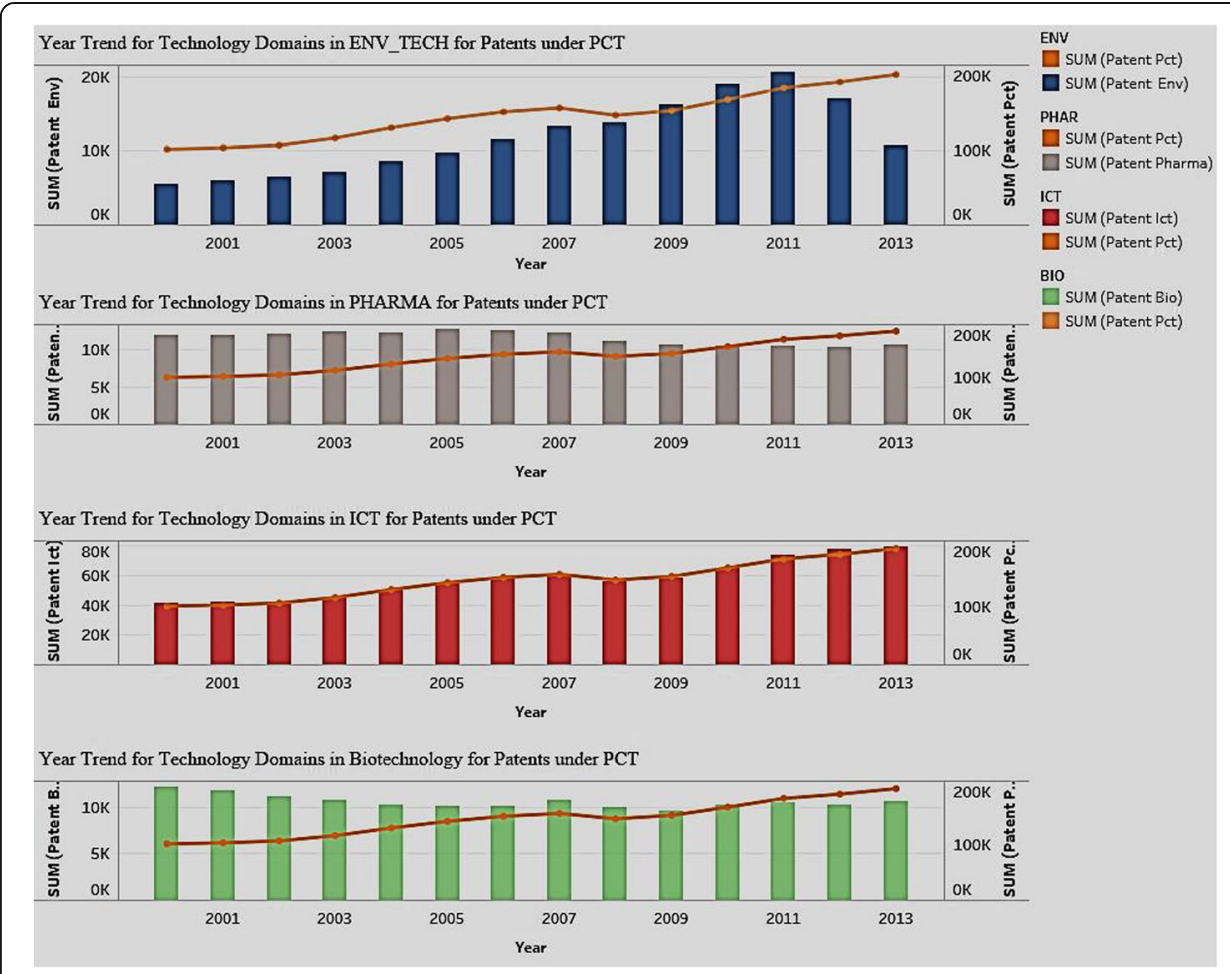

Fig. 16 Distribution of patents under PCT for various technology domains

2011 to 2013. That said, the total number of PCT patents over the years shows a trend of increase. The biotechnology sector includes technological applications that use biological systems or living organisms to develop or make products for specific use. The number of patents in the pharmaceutical and biotechnology sectors has been increasing over the years. Among all the sectors and throughout the time span we studied, ICT saw a high number of patents and a consistently positive trend. The number of patents in this sector equals the total number under PCT, highlighting the overall dominance of the ICT sector in the patent industry.

We then looked for significant associations among sets of innovation indicators. We started with expenditure on $R \& D$ and the $R \& D$ personnel in the sectors of business, government, and higher education.

\section{Association between R\&D expenditure and R\&D personnel}

Governments use R\&D statistics collected by countries from businesses to make and monitor policy related to national science and technology. These stats also feed into national economic statistics, such as GDP and net worth. Different performance sectors may have different kinds of associations between R\&D expenditure and personnel. Figure 17 shows the associations between BERD and R\&D personnel in the business sector.

Figure 17 shows a significant positive association $(p<0.0001)$ in the business sector between expenditure on $R \& D(B E R D)$ and $R \& D$ personnel. Interestingly, the implication is that we should also see an increase in R\&D personnel in this sector. But this is not the case when we break down the analysis by region. In Latin America and Caribbean, while the percentage of researchers in the business sector is high, the 


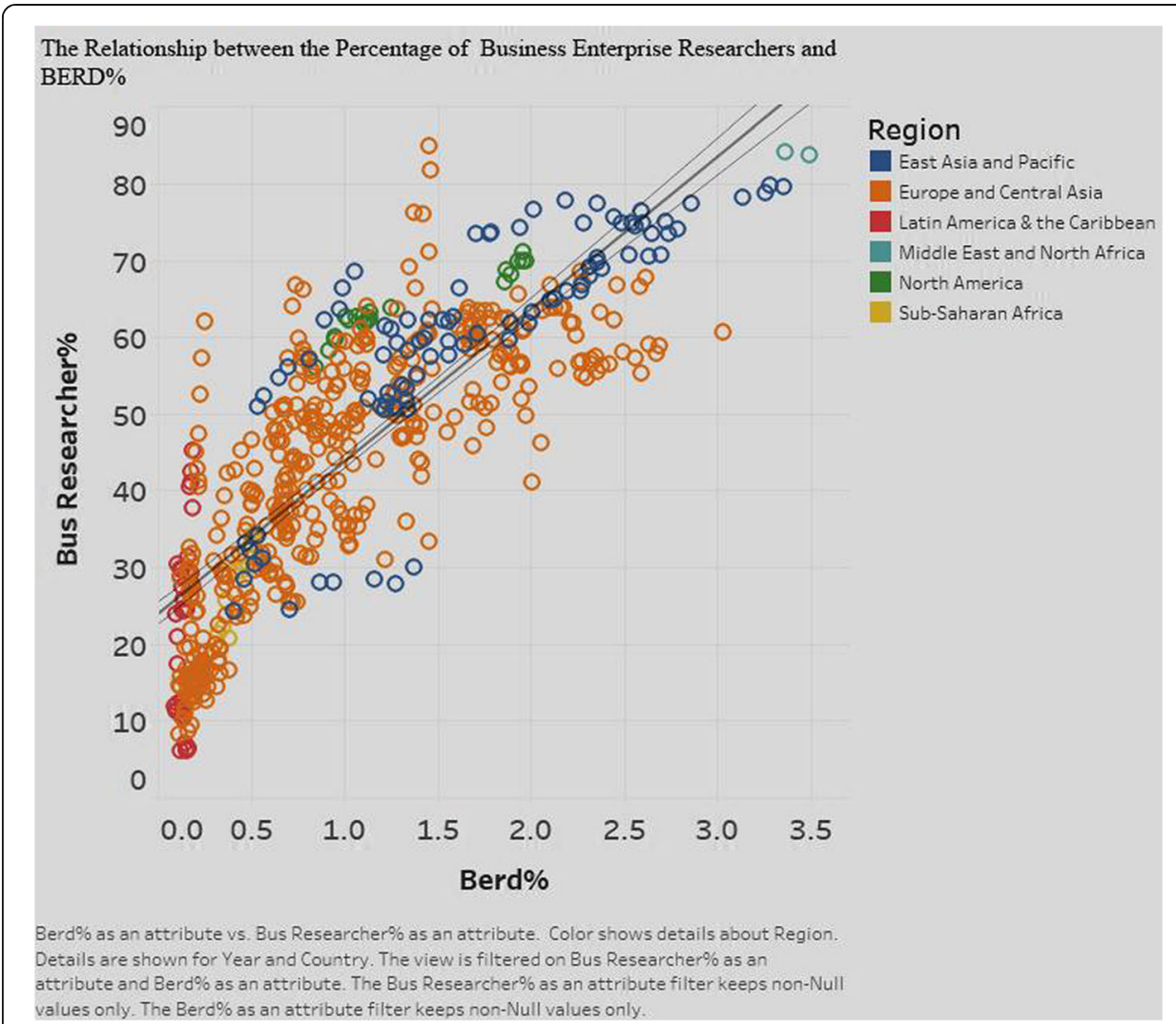

Fig. 17 Association between BERD and R\&D personnel in business enterprise sector

expenditure is consistently low for all countries in the region. The explanation is that in developing regions such as these, while there is recognition of the need to focus on R\&D by employing more personnel, the cost of deployment is relatively low. By contrast, in North America, both the R\&D expenditure and R\&D personnel are high, likely because of the high cost of deployment of personnel. In East Asia and Pacific, while some countries are high in both business expenditure and personnel, others are low in both. Across all regions, some countries show a large business expenditure on R\&D with no associated increase in personnel. Examples include Israel in Latin America and Caribbean, Japan in East Asia and Pacific, and Slovenia in Europe and Central Asia. On the flip side, there are countries, Romania and Ireland (in the region of Europe and Central Asia) among them, that show a large fluctuation in personnel with little change in expenditure. In general, there is a positive association between $R \& D$ expenditure and $R \& D$ personnel in the business sector.

Figure 18 shows the analysis of $R \& D$ personnel and intramural expenditure on $R \& D$ (GOVERD) for the government sector.

Figure 18 shows a significant positive association $(p<0.0001)$ between GOVERD and R\&D personnel. Though the region of East Asia and Pacific is similar to Latin America and Caribbean in government expenditure on R\&D, it has a lower percentage of $R \& D$ personnel. This can be attributed to a relatively high cost of labor in East Asia \& Pacific compared to Latin America \& Caribbean. In North America, 


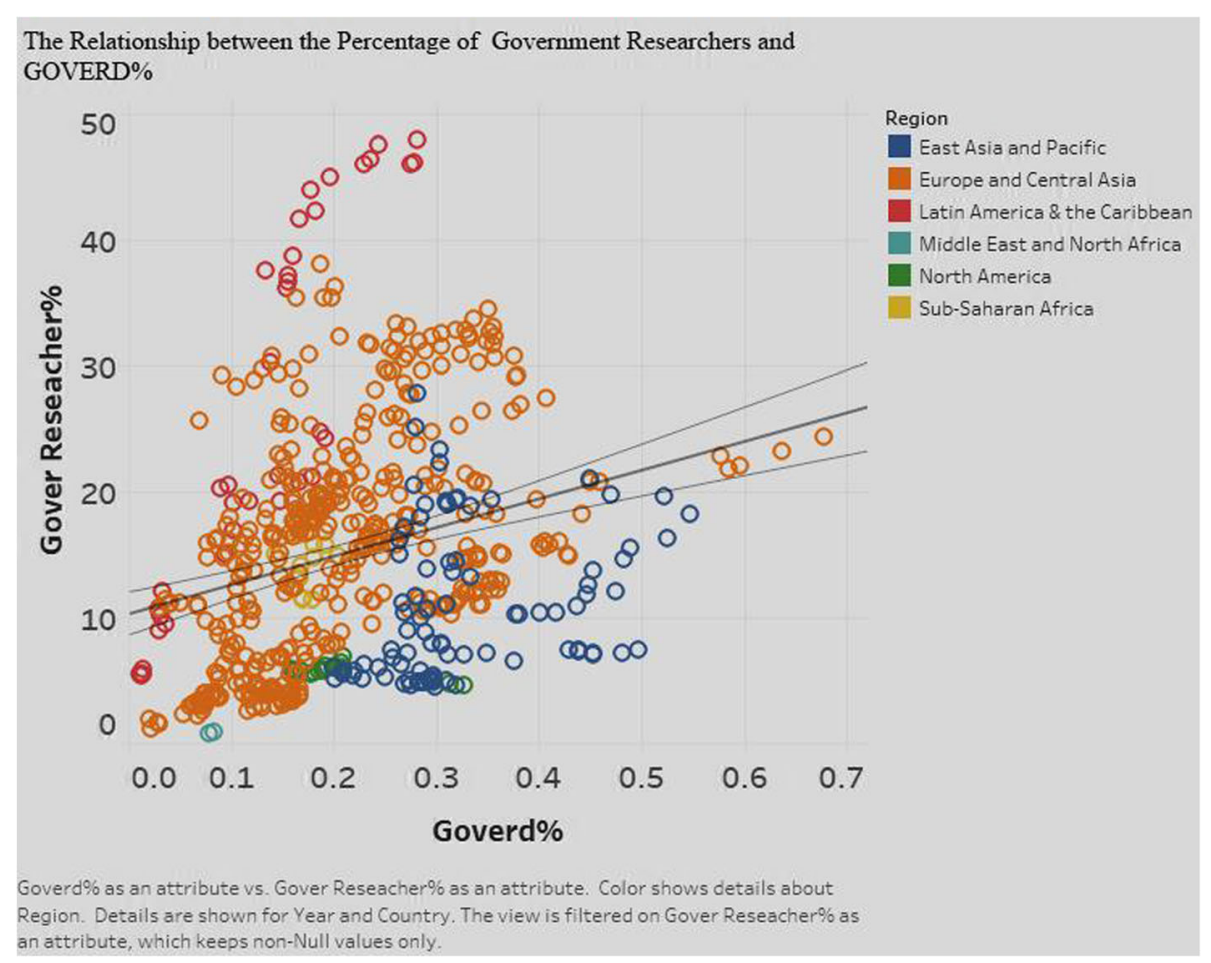

Fig. 18 Association between GOVERD and R\&D personnel in government sector

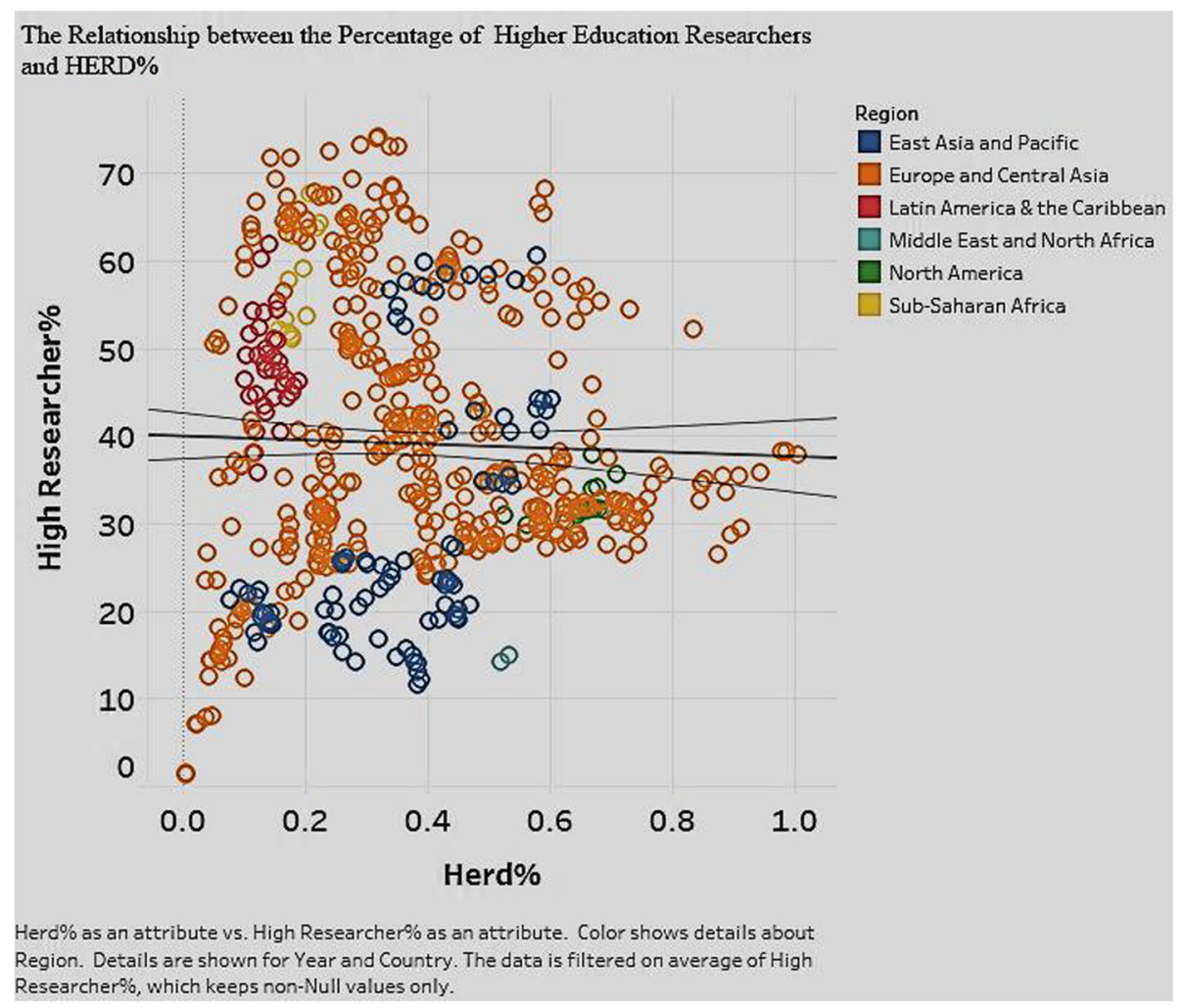

Fig. 19 Association between HERD and R\&D personnel in higher education 


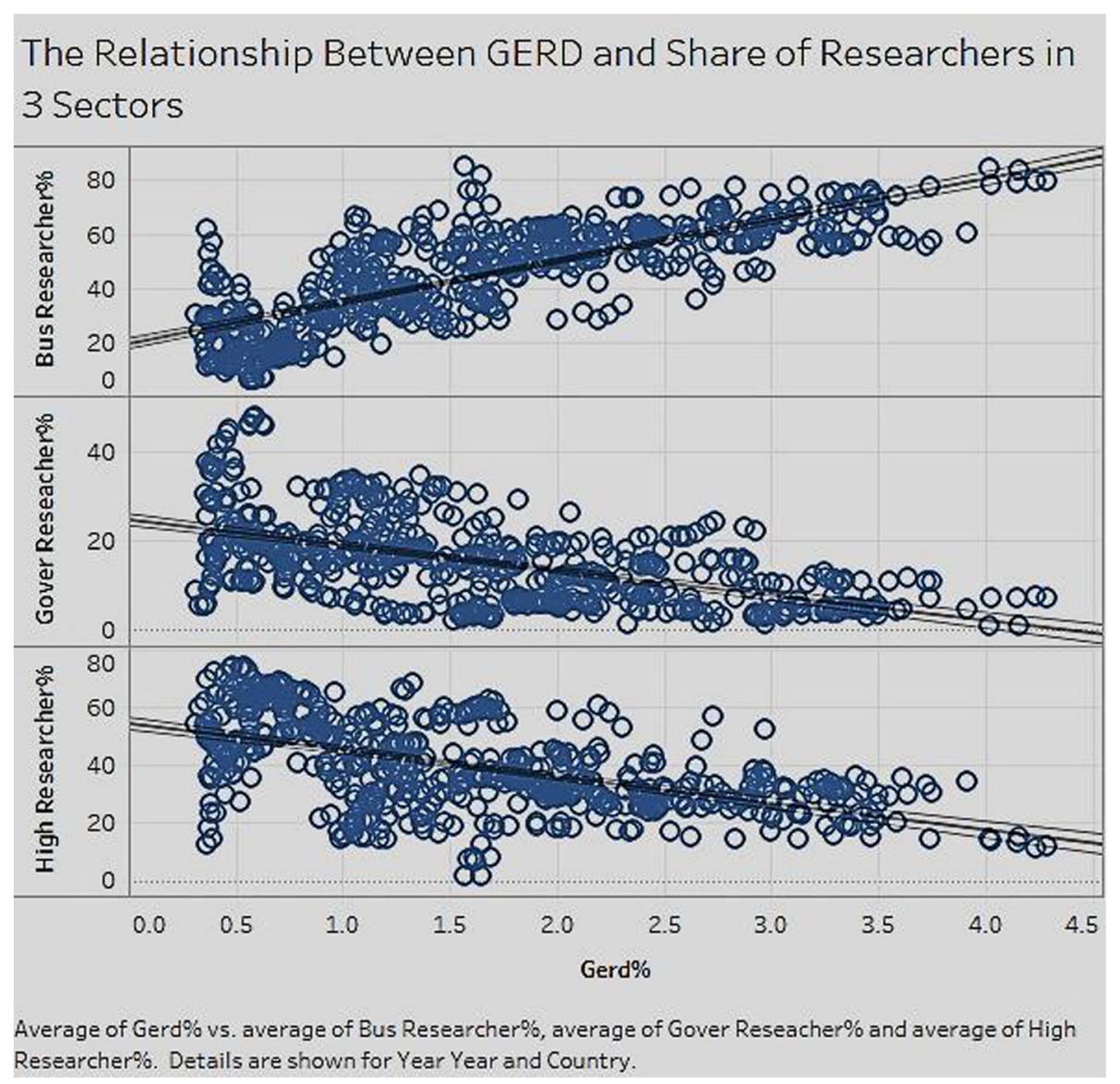

Fig. 20 Association between GERD and R\&D personnel in the sectors

both expenditure and personnel are lower than those of East Asia \& Pacific. This is due to the increased emphasis on $R \& D$ by the business sector over the government. Figure 19 shows the relationship between expenditure and personnel in the higher education sector (HERD).

In the case of higher education (Fig. 19), we did not find a significant association between the expenditure on R\&D and the percentage of researchers $(p>0.05)$.

It is important to analyze gross domestic expenditure on R\&D (GERD) because it represents an aggregate of the sectors of business, government, and higher education and because it is considered the preferred method for international comparisons of overall R\&D expenditure. Figure 20 shows the relationship between expenditure (GERD) and R\&D personnel in all the sectors.

The relationship between GERD and the percentage of researchers is significant and positive $(p<0.0001)$ for the business sector, but significant and negative $(p<$ 0.001 ) for the government and higher education sectors. This means that in the business sector, an increase in expenditure is associated with an increase in the R\&D personnel percentage of researchers). In the government and higher education sectors, an increase in expenditure is associated with a decrease in personnel. This highlights the fact that, in general, most of the R\&D expenditure and personnel come from the business sector and not from the government or 


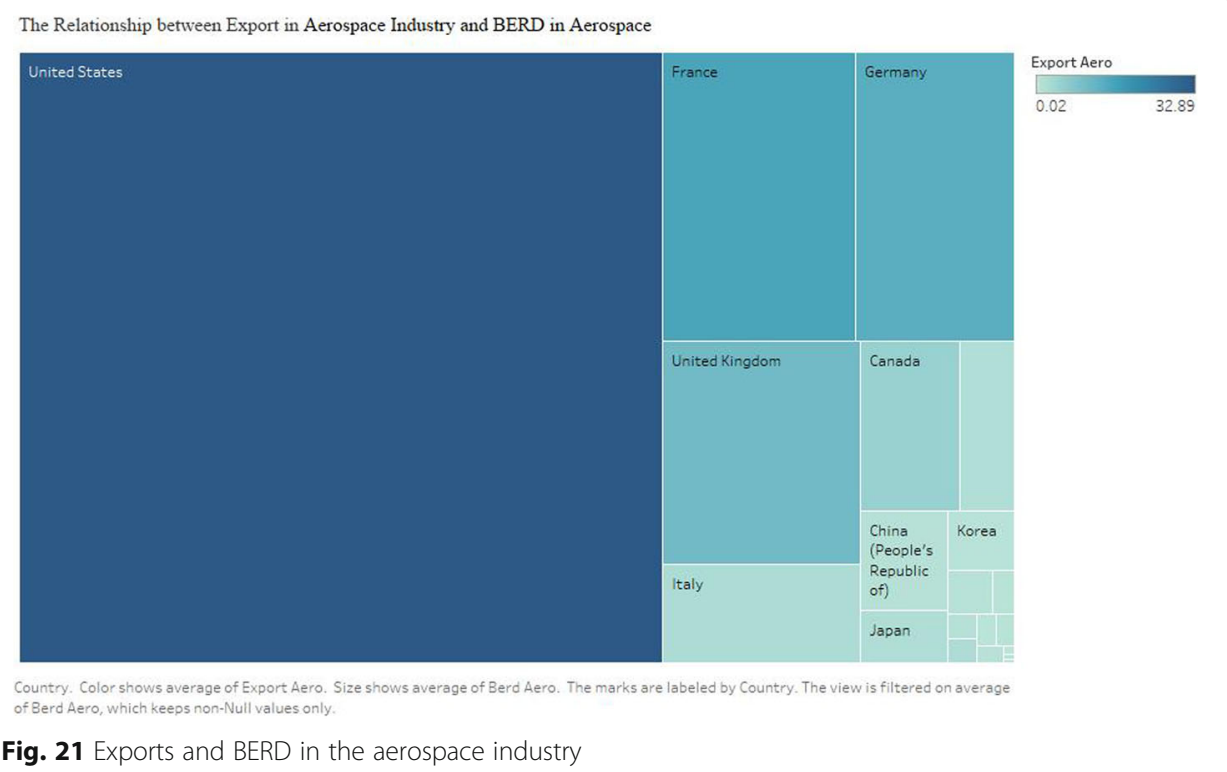

higher education sectors. We searched for associations between national exports and business expenditure on R\&D (BERD) by industry to see if there were dominant patterns.

\section{Association between exports and BERD by industry}

We analyze business expenditure on R\&D and exports for different industries. Figure 21 shows the analysis for the aerospace industry.

Figure 21 depicts the exports and BERD for the aerospace industry for each country. The intensity of the color indicates the quantity of exports, while grid size denotes expenditure. Only countries for which data can be adequately mapped are shown in the

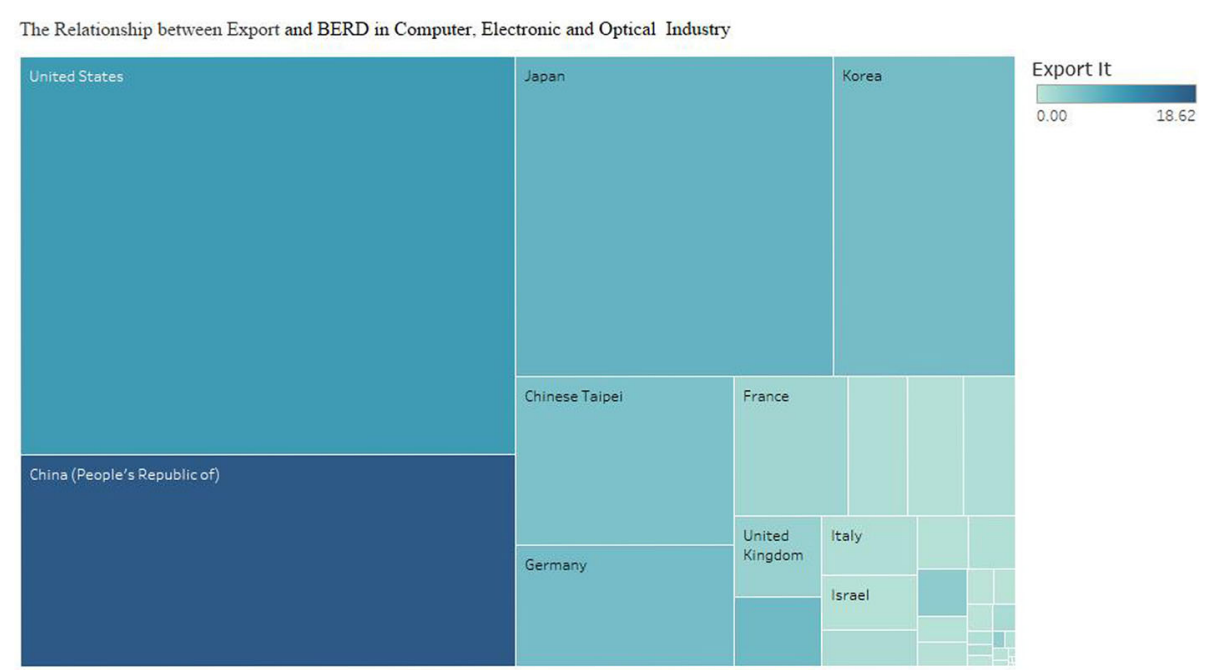

Country. Color shows average of Export it. Size shows average of Berd It. The marks are labeled by Country

Fig. 22 Exports and BERD in computer, electronic, and optical industry 


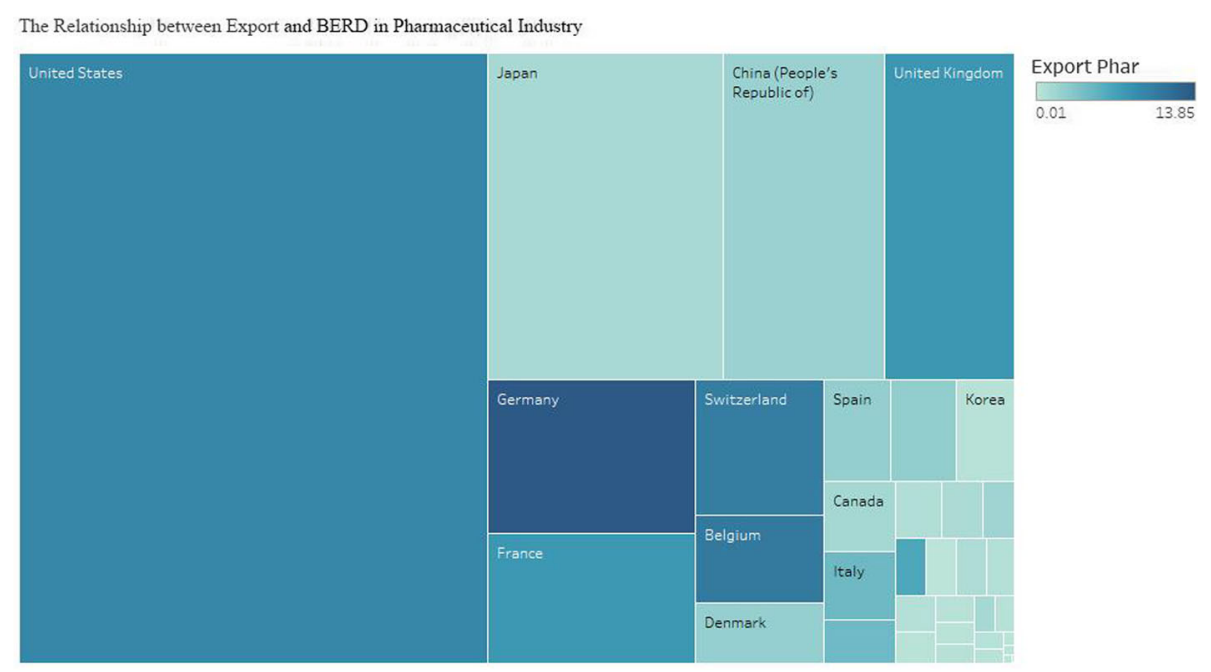

Country. Color shows average of Export Phar. Size shows average of Berd Phar. The marks are labeled by Country.

Fig. 23 Exports and BERD in pharmaceutical industry

diagram. The USA is the leader in exports and expenditure in this industry. France, Germany, the UK, and others show high exports and relatively low expenditure. Japan and China are low in both expenditure and exports in the aerospace industry. Figure 22 shows the exports and business expenditure on $R \& D$ for the computer/electronic/optical industry.

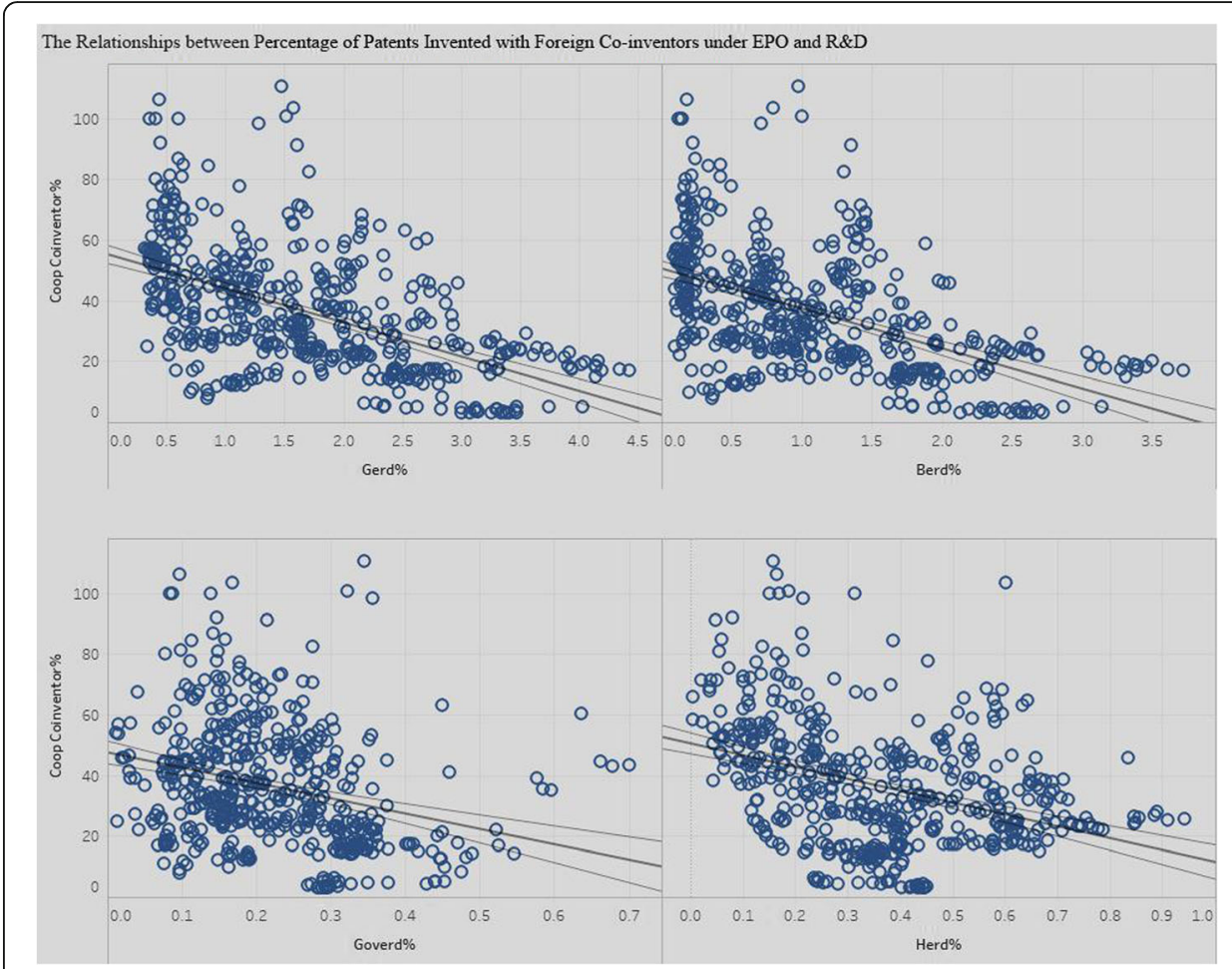

Fig. 24 Association between patents with foreign co-inventors and R\&D expenditure 


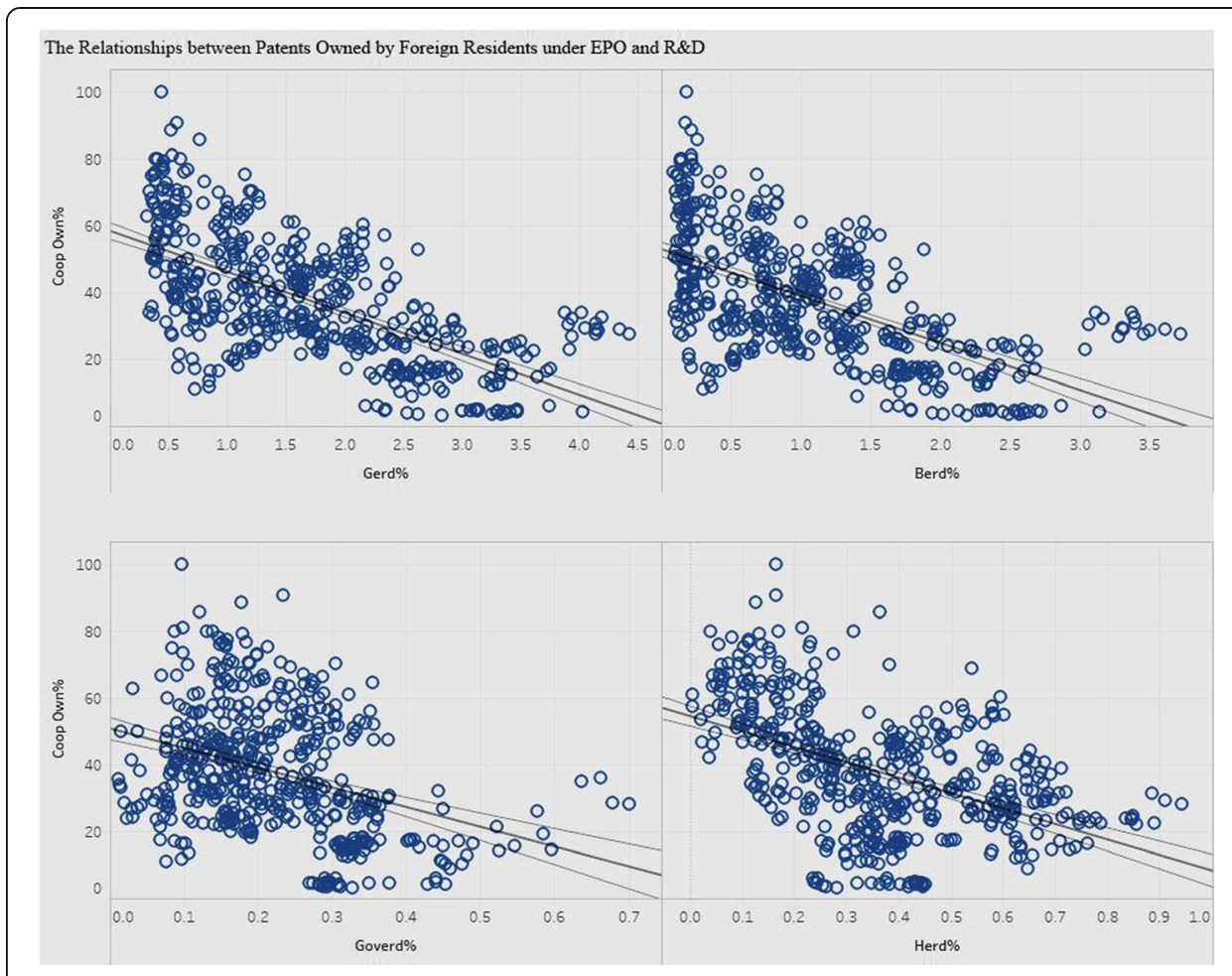

Fig. 25 Association between patents owned by foreign residents and R\&D expenditure

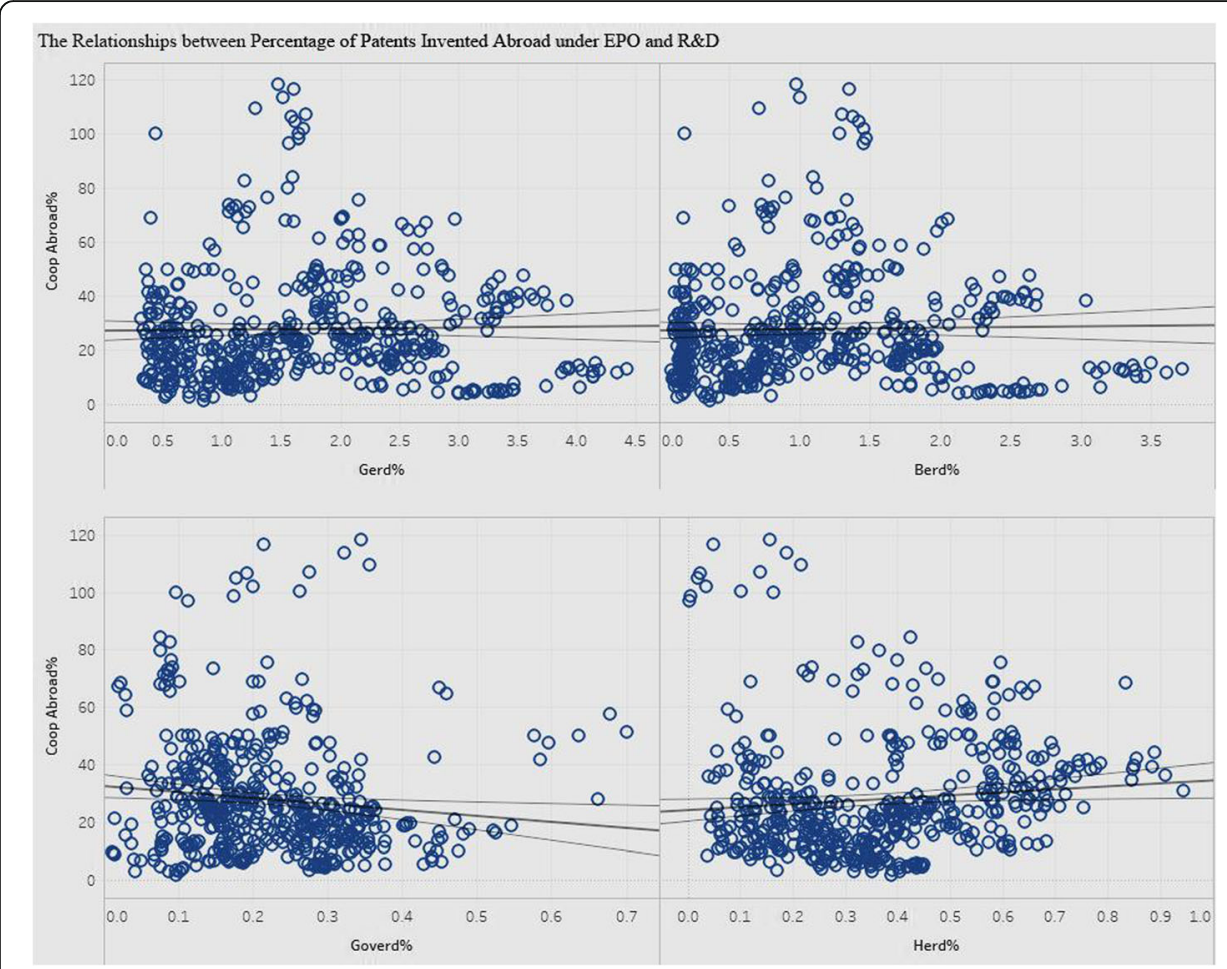

Fig. 26 Association between patents invented abroad and R\&D expenditure 
In the computer/electronic/optical industry, the USA leads China, Japan, and Korea in terms of expenditure. In terms of exports, China is the leader. While the UK performed well in exports in the aerospace industry (shown in Fig. 21), it fares low in both exports and expenditure in the computer/electronic/optical industry. Italy and Israel show very low exports and expenditure in this industry. Figure 23 illustrates the analysis of exports and business expenditure for the pharmaceutical industry.

Figure 23 shows the USA leading in business expenditure on R\&D in the pharmaceutical industry. In exports, Germany takes the lead, followed by the USA, the UK, France, Switzerland, and Belgium. China and Japan have very low exports but moderate

Table 3 Missing value percentages for variables

\begin{tabular}{|c|c|c|}
\hline Variable name & Number of missing values & Missing percentage \\
\hline BERD\% & 51 & 8 \\
\hline BERD_SERVICE & 233 & 35 \\
\hline BERD_AERO & 442 & 66 \\
\hline BERD_IT & 245 & 36 \\
\hline BERD_PHAR & 281 & 42 \\
\hline GERD\% & 56 & 8 \\
\hline GOVERD\% & 48 & 7 \\
\hline GOVER_RESEACHER\% & 101 & 15 \\
\hline BUS_RESEARCHER\% & 96 & 14 \\
\hline HERD\% & 49 & 7 \\
\hline HIGH_RESEARCHER\% & 108 & 16 \\
\hline EXPORT_AERO & 0 & 0 \\
\hline EXPORT_IT & 0 & 0 \\
\hline EXPORT_PHAR & 0 & 0 \\
\hline PATENT_BIO & 51 & 8 \\
\hline PATENT_ICT & 42 & 6 \\
\hline PATENT_TRIADIC & 42 & 6 \\
\hline PATENT_PCT & 42 & 6 \\
\hline COOP_COINVENTOR\% & 126 & 19 \\
\hline COOP_OWN\% & 126 & 19 \\
\hline COOP_ABROAD\% & 134 & 20 \\
\hline PATENT_ENV & 101 & 15 \\
\hline PATENT_PHARMA & 86 & 13 \\
\hline GERD_BUS_PERFORM & 59 & 9 \\
\hline GERD_GOV_PERFORM & 59 & 9 \\
\hline GERD_HIGH_PERFORM & 59 & 9 \\
\hline GERD_PRIVATE_PERFORM & 228 & 34 \\
\hline GERD_OTHER_FINANCE & 136 & 20 \\
\hline GERD_GOV_FINANCE & 116 & 17 \\
\hline GERD_IND_FINANCE & 116 & 17 \\
\hline GERD_ABROAD_FINANCE & 125 & 19 \\
\hline EPO & 84 & 13 \\
\hline Total & 3442 & 16 \\
\hline
\end{tabular}


expenditure, while Canada and Korea are low in both exports and expenditure in the pharmaceutical industry.

Overall, the USA ranks high in exports and expenditure on R\&D, in all three industries; China does best in the computer industry; Japan does better in the computer and pharmaceutical industries than in aerospace; and the UK fares best in the pharmaceutical industry. Countries can use these findings to adjust their resource allocations to $R \& D$ in terms of industries.

\section{Association between patents and $R \& D$ expenditure}

We analyzed the association between R\&D expenditure and international cooperation in patents (Figs. 24, 25, and 26).

Figure 24 shows the association between the percentage of patents invented with co-inventors and the four kinds of $R \& D$ expenditure. The association is significant $(p<0.0001)$ and negative for all types of R\&D expenditure (GERD, BERD, GOVERD, HERD). With an increase in the percentage of R\&D expenditure from any sector, the percentage of patents invented with co-inventors decreases, implying more local innovation. This holds promise for countries trying to enhance innovation in terms of their contribution to GDP.

For patents owned by foreign residents (Fig. 25), there is a significant negative relationship $(p<0.0001)$ with all four types of R\&D expenditures. With an increase in expenditure on $R \& D$ in any sector, there is a decrease in the percentage of patents owned by foreign residents. Specifically, our analyses reveals that with a $1 \%$ increase in gross expenditure on $R \& D$, the $\%$ of patents owned by foreign residents decreases by $12.27 \%$; in case of business expenditure, the \% of patents decreases by $14.07 \%$; in case of government and education expenditure, the decrease is significant with $58.95 \%$ and $46.25 \%$ respectively.

However, the association of $R \& D$ expenditure with patents invented abroad (Fig. 26) differs from that with patents invented with co-inventors and with foreign residents. There are significant and moderately positive associations between

Table 4 Descriptive statistics for the variables

\begin{tabular}{|c|c|c|c|c|c|c|c|c|c|c|c|c|c|c|c|c|}
\hline & & & & & & & & & & & & & & & & \\
\hline Yean & 1.10 & 1.71 & 0.22 & & 5.44 & 44.77 & 0.38 & 38.66 & 2.25 & 1.97 & 2.29 & 248.41 & 1359.25 & 1309.51 & 3504. 88 & 3068.20 \\
\hline Standard Error & 0.03 & 0.04 & 0.00 & & 0.38 & 0.69 & 0.01 & 0.59 & 0.23 & 0.15 & 0.14 & 28.25 & 139.72 & 137.90 & 331. 38 & 258.83 \\
\hline Yedian & 0.94 & 1.60 & 0.20 & & 14.58 & 47.56 & 0.36 & 35.51 & 0.29 & 0.53 & 0.45 & 44.22 & 182.57 & 103.55 & 714.48 & 450.73 \\
\hline Yode & 0.62 & 1.08 & 0.15 & & 6.46 & 34.18 & 0.23 & 27.63 & $\mathrm{AN} / \mathrm{A}$ & $\mathbb{A N} / \mathrm{A}$ & $\pm \mathrm{N} / \mathrm{A}$ & 2.00 & 583.06 & 84.71 & 1152.96 & 65.58 \\
\hline Standard Deviation & 0.81 & 0.97 & 0.11 & & 9.77 & 17.81 & 0.21 & 15.18 & 5.94 & 3.76 & 3.58 & 732.26 & 3622.00 & 3574.79 & 8590.38 & 6709.77 \\
\hline Sample Variance & 0.66 & 0.95 & 0.01 & & 95.38 & 317.07 & 0.04 & 230.44 & 35.28 & 14. 15 & 12.83 & $536204.60 \mathrm{I}$ & 13118887.17 & 12779104.77 & 73794616.38 & 45020983.27 \\
\hline Rurtosis & 0.30 & -0.37 & 1.05 & & 0.54 & $-0.84-x$ & -0.33 & -0.67 & 15.88 & 19.00 & 2.40 & 34.10 & 16.78 & 13. 28 & 17.26 & 10.02 \\
\hline Skenness & 0.90 & 0.60 & 0.75 & & 0.90 & -0.19 & 0.47 & 0.34 & 3.87 & 3.86 & 1.84 & 5.67 & 4.08 & 3.76 & 4.07 & 3.22 \\
\hline Range & 3.63 & 4. 12 & 0.69 & & 17.24 & 78.81 & 1.00 & 72.84 & 36.62 & 28.12 & 15.58 & 6199.24 & 23530.89 & 18702.55 & 58870.04 & 37575.72 \\
\hline Vinimum & 0.09 & 0.31 & 0.01 & & 0.79 & 6.20 & 0.00 & 1.34 & 0.00 & 0.00 & 0.01 & 0.13 & 0.50 & 0.27 & 8.83 & 5.13 \\
\hline Laximum & 3.72 & 4.43 & 0.70 & & 48.03 & 85.01 & 1.01 & 74.18 & 36.62 & 28.12 & 15.59 & 6199.37 & 23536.39 & 18702.82 & 58878.87 & 37580.85 \\
\hline Sum & $739.33:$ & 1151.84 & 147.17 & 10376 . & 6.96 & $30088.66 \quad 25$ & 252.09 & 25981.53 & 1513.70 & 1320.81 & 1539.02 & 166933.82 & 913415.33 & 879991.83 & 32355279.02 & 2061830.51 \\
\hline \multirow[t]{2}{*}{ Count } & 672 & 672 & 672 & & 672 & 672 & 672 & 672 & 672 & 672 & 672 & 672 & 672 & 672 & 672 & 672.00 \\
\hline & COOP_COIIVIVI & Wentorte a & 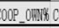 & COOP_ABPOACY I & PATE & PATENT PHAR & PRA GRRI & PERPOPUIGER & PERPORYG G & ER__HG__PE & ERPOPH GERD, & THER_FIIAACEC & 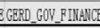 & EGERD_IND_PI & FINAICB GRR___ & POAD_FIIIANCE \\
\hline Hean & & 36.10 & 37.08 & 28.03 & 285.75 & 274.8 & 188 & 57.47 & 16.47 & & 24.62 & 4.41 & 37.20 & & 49.16 & 9.21 \\
\hline Standard Error & & 0.76 & 0.69 & 0.81 & 27.96 & & .25 & 0.57 & 0.37 & & 0.42 & 0.21 & 0.50 & & 0.55 & 0.33 \\
\hline Yedian & & 32.60 & 34.32 & 22.63 & 49.51 & & .77 & 59.89 & 14.01 & & 24.60 & 2.68 & 35.61 & & 48.04 & 7.21 \\
\hline Yode & & 55.56 & 55.56 & 50.00 & 1.00 & & .00 & 67.15 & 27.07 & & 35.91 & 23.95 & 12.45 & & 36.48 & 0.02 \\
\hline Standard Deviation & & 19.67 & 18.01 & 20.92 & 724.83 & 784. & 15 & 14.87 & 9.67 & & 10.82 & 5.41 & 13.03 & & 14.38 & 8.53 \\
\hline Sanple Variance & & 366.78 & 324. 42 & 437.54 & 525384.44 & 614892. & & 221.25 & 93.47 & & 117.12 & 29.23 & 169.75 & & 206.90 & 72.82 \\
\hline Kurtosis & & 1.00 & -0.14 & 3.04 & 22.32 & & 42 & -0.55 & 0.20 & & 0.47 & 5.67 & -0.11 & & -0.73 & 5.66 \\
\hline Skemess & & 0.86 & 0.38 & 1.62 & 4.42 & & 62 & -0.45 & 0.81 & & 0.48 & 2.39 & 0.48 & & 0.14 & 1.94 \\
\hline Range & & 107.39 & 96.68 & 116.68 & 6103.95 & 5976.2 & 21 & 72.55 & 48.49 & & 67.62 & 24.36 & 66.67 & & 74. 17 & 51.60 \\
\hline Yinimun & & 3.14 & 3.32 & 1.55 & 0.20 & & .33 & 20.06 & 0.74 & & 0.25 & 0.08 & 7.67 & & 16.51 & 0.02 \\
\hline Maximun & & 110.53 & 100.00 & 118.23 & 36104.15 & 5976.5 & & 92.61 & 49.23 & & 67.87 & 24.44 & 74.34 & & 90.68 & 51.61 \\
\hline Sin & & 4261.76 & 24915.55 & 18887.23 & 192021.94 & 184719.2 & & 38621.10 & 11069.23 & & 542.34 & 2965.46 & 25001.56 & & 3036.96 & 6191.00 \\
\hline Count & & 672.00 & 672.00 & 672.00 & 672.00 & 672. & .00 & 672.00 & 672.00 & & 672.00 & 672.00 & 672.00 & & 672.00 & 672.00 \\
\hline
\end{tabular}




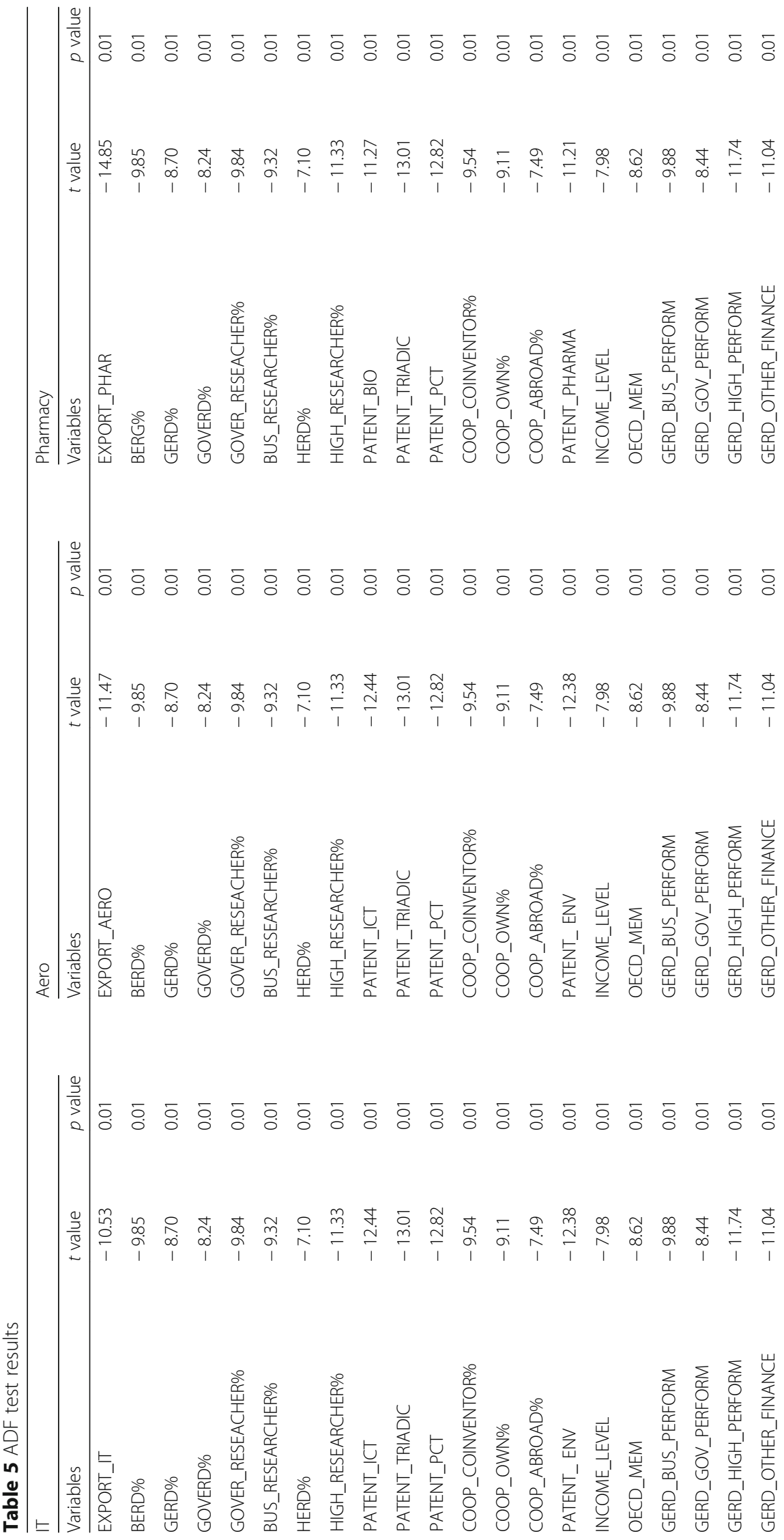




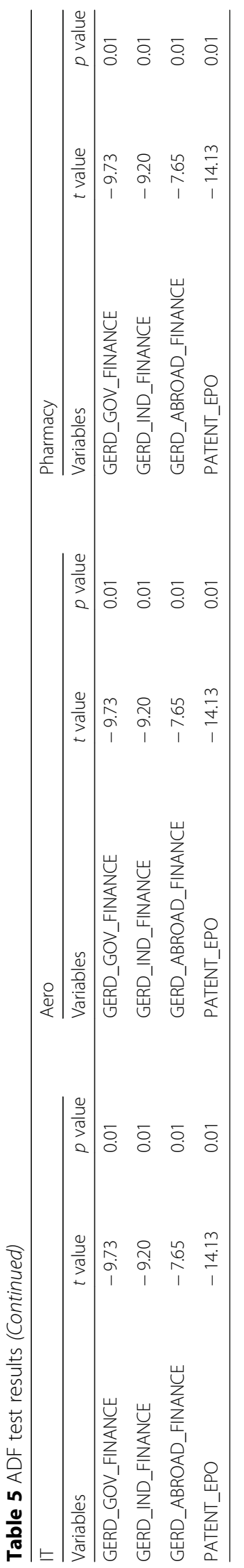


Table 6 VIF tests before and after multicollinearity analysis

\begin{tabular}{|c|c|c|c|c|c|}
\hline \multicolumn{6}{|c|}{ VIF Test Result for Three Industries before Multicollinearity Analysis } \\
\hline \multicolumn{2}{|c|}{ Compture Industry } & \multicolumn{2}{|l|}{ Aerospace Industry } & \multicolumn{2}{|c|}{ Pharamcy Industry } \\
\hline Variables & VIF & Variables & VIF & Variables & VIF \\
\hline BERD. & 50.317496 & BERD. & 50.317496 & BERD. & 50.534246 \\
\hline GERD. & 61.833875 & GERD. & 61.833875 & GERD. & 62.014975 \\
\hline GOVERD. & 3.66587 & GOVERD. & 3.66587 & GOVERD. & 3.664599 \\
\hline GOVER_RESEACHER. & 11.102074 & GOVER_RESEACHER. & 11.102074 & GOVER_RESEACHER. & 11.171419 \\
\hline BUS_RESEARCHER. & 26.904011 & BUS_RESEARCHER. & 26.904011 & BUS_RESEARCHER. & 26.912451 \\
\hline HERD. & 5.869968 & HERD. & 5.869968 & HERD. & 5.834039 \\
\hline HIGH_RESEARCHER. & 19.978196 & HIGH_RESEARCHER. & 19.978196 & HIGH_RESEARCHER. & 19.99408 \\
\hline PATENT_ICT & 22.684805 & PATENT_ICT & 22.684805 & PATENT_BIO & 17.122477 \\
\hline PATENT_TRIADIC & 7.496497 & PATENT_TRIADIC & 7.496497 & PATENT_TRIADIC & 7.405432 \\
\hline PATENT_PCT & 43.539001 & PATENT_PCT & 43.539001 & PATENT_PCT & 12.375165 \\
\hline COOP_COINVENTOR. & 3.985236 & COOP_COINVENTOR. & 3.985236 & COOP_COINVENTOR. & 3.977808 \\
\hline COOP_OWN. & 4.317274 & COOP_OWN. & 4.317274 & COOP_OWN. & 4.293641 \\
\hline COOP_ABROAD. & 2.110285 & COOP_ABROAD. & 2.110285 & COOP_ABROAD. & 2.100991 \\
\hline PATENT_.ENV & 7.453439 & PATENT_ENV & 7.453439 & PATENT_PHARMA & 13.450522 \\
\hline INCOME_LEVEL & 3.672462 & INCOME_LEVEL & 3.672462 & INCOME_LEVEL & 3.668015 \\
\hline OECD_MEM & 3.227714 & OECD_MEM & 3.227714 & OECD_MEM & 3.198357 \\
\hline GERD_BUS_PERFORM & 17.997905 & GERD_BUS_PERFORM & 17.997905 & GERD_BUS_PERFORM & 17.986854 \\
\hline GERD_GOV_PERFORM & 10.68529 & GERD_GOV_PERFORM & 10.68529 & GERD_GOV_PERFORM & 10.685089 \\
\hline GERD_HIGH_PERFORM & 11.487267 & GERD_HIGH_PERFORM & 11.487267 & GERD_HIGH_PERFORM & 11.60147 \\
\hline GERD_OTHER_FINANCE & 2.275149 & GERD_OTHER_FINANCE & 2.275149 & GERD_OTHER_FINANCE & 2.296682 \\
\hline GERD_GOV_FINANCE & 14.062001 & GERD_GOV_FINANCE & 14.062001 & GERD_GOV_FINANCE & 14.07488 \\
\hline GERD_IND_FINANCE & 16.829874 & GERD_IND_FINANCE & 16.829874 & GERD_IND_FINANCE & 16.791631 \\
\hline GERD_ABROAD_FINANCE & 5.439217 & GERD_ABROAD_FINANCE & 5.439217 & GERD_ABROAD_FINANCE & 5.446633 \\
\hline PATENT_EPO & 9.823224 & PATENT_EPO & 9.823224 & PATENT_EPO & 8.614441 \\
\hline \multicolumn{6}{|c|}{ VIF Test Result for Three Industries after Multicollinearity Analysis } \\
\hline \multicolumn{2}{|c|}{ Compture Industry } & \multicolumn{2}{|c|}{ Aerospace Industry } & \multicolumn{2}{|c|}{ Pharamcy Industry } \\
\hline Variables & VIF & Variables & VIF & Variables & VIF \\
\hline BERD. & 6.875148 & BERD. & 6.875148 & BERD. & 6.875148 \\
\hline GOVERD. & 2.528901 & GOVERD. & 2.528901 & GOVERD. & 2.515218 \\
\hline GOVER_RESEACHER. & 5.731884 & GOVER_RESEACHER. & 5.731884 & GOVER_RESEACHER. & 5.825525 \\
\hline HERD. & 3.908161 & HERD. & 3.908161 & HERD. & 3.862613 \\
\hline HIGH_RESEARCHER. & 4.006001 & HIGH_RESEARCHER. & 4.006001 & HIGH_RESEARCHER. & 4.001459 \\
\hline PATENT_ICT & 6.236076 & PATENT_ICT & 6.236076 & PATENT_TRIADIC & 5.659744 \\
\hline PATENT_TRIADIC & 7.451674 & PATENT_TRIADIC & 7.451674 & COOP_COINVENTOR. & 3.936043 \\
\hline COOP_COINVENTOR. & 3.934443 & COOP_COINVENTOR. & 3.934443 & COOP_OWN. & 4.223912 \\
\hline COOP_OWN. & 4.255438 & COOP_OWN. & 4.255438 & COOP_ABROAD. & 2.046281 \\
\hline COOP_ABROAD. & 2.048209 & COOP_ABROAD. & 2.048209 & PATENT_PHARMA & 3.357131 \\
\hline PATENT_ENV & 6.451818 & PATENT_ENV & 6.451818 & INCOME_LEVEL & 3.590275 \\
\hline INCOME_LEVEL & 3.598586 & INCOME_LEVEL & 3.598586 & OECD_MEM & 3.166582 \\
\hline OECD_MEM & 3.189111 & OECD_MEM & 3.189111 & GERD_GOV_PERFORM & 7.609693 \\
\hline GERD_GOV_PERFORM & 7.609713 & GERD_GOV_PERFORM & 7.609713 & GERD_HIGH_PERFORM & 5.827781 \\
\hline GERD_HIGH_PERFORM & 5.782097 & GERD_HIGH_PERFORM & 5.782097 & GERD_OTHER_FINANCE & 1.717704 \\
\hline GERD_OTHER_FINANCE & 1.685751 & GERD_OTHER_FINANCE & 1.685751 & GERD_GOV_FINANCE & 4.558544 \\
\hline GERD_GOV_FINANCE & 4.485495 & GERD_GOV_FINANCE & 4.485495 & GERD_ABROAD_FINANCE & 1.459669 \\
\hline GERD_ABROAD_FINANCE & 1.437382 & GERD_ABROAD_FINANCE & 1.437382 & PATENT_EPO & 7.582291 \\
\hline PATENT_EPO & 6.592413 & PATENT_EPO & 6.592413 & & \\
\hline
\end{tabular}

patents invented abroad and R\&D expenditure in all sectors, with the exception of government. As the R\&D expenditure in the business or higher education increases, the percentage of patents invented abroad increases. In the face of increasing expenditure, local innovation becomes more expensive, leading to more foreign collaboration. The exception is with government expenditure. In this case, the relationship is significantly negative in that as the government expenditure on $R \& D$

Table 7 Comparison of pooling and fixed effects models for computer industry

\begin{tabular}{|c|c|c|c|c|c|}
\hline \multicolumn{6}{|c|}{ Comparison Results of Pooling \& Fixed Effects Model for Computer Industry } \\
\hline \multicolumn{5}{|c|}{ F Statistic Test } & \multirow{3}{*}{$\frac{\text { Results }}{\text { Individual Fixed Effects }}$} \\
\hline $\begin{array}{c}\text { Mixed Effects and } \\
\text { Individual Fixed Effects }\end{array}$ & $F=48.656$ & $\mathrm{df1}=39$ & $\mathrm{df} 2=613$ & $\mathrm{p}$-value $<2.2 \mathrm{e}-16$ & \\
\hline $\begin{array}{l}\text { Mixed Effects and Time } \\
\text { Fixed Effects }\end{array}$ & $\mathrm{F}=0.6000$ & $\mathrm{df} 1=15$ & $\mathrm{df} 2=637$ & p-value $=0.8761$ & \\
\hline $\begin{array}{l}\text { Time Fixed Effects and } \\
\text { Individual Fixed Effects }\end{array}$ & $\mathrm{F}=77.608$ & $\mathrm{df1}=24$ & $\mathrm{df} 2=613$ & $\mathrm{p}$-value $<2.2 \mathrm{e}-16$ & Individual Fixed Effects \\
\hline
\end{tabular}


Table 8 Test results of random effects for computer industry

\begin{tabular}{ccc}
\hline \multicolumn{3}{c}{ Test Results of Random Effects } \\
\hline L-M Test \\
\hline chisq $=300.57$ & $\mathrm{df}=16$ & p-value $<2.2 \mathrm{e}-16$ \\
\hline
\end{tabular}

increases, the percentage of patents invented abroad decreases. This finding has important policy implications for governments of developing countries, which should direct more resources to $R \& D$ with a view to improving local innovation and its contribution to GDP. This is discussed in detail in the conclusions section.

We now discuss our second approach of econometric panel analysis.

\section{Econometric panel analysis}

Our panel analysis follows a threefold structure: first, we perform a regression analysis on exports for each industry; we then analyze the influence of $R \& D$ expenditure on patents; and lastly, we explore the international ownership of and investment in patents and the influence on exports. We deploy the PLM package of $\mathrm{R}$ for all the analyses.

There are certain steps that need to be taken in order to prepare the data for panel analysis. As a first step to ensuring integrity, we inspected the dataset for missing data (Table 3). As the results show, some variables had more than $20 \%$ missing values. We deleted these and used the Random Forest algorithm to fill in values for the remaining variables.

The descriptive statistics for the complete dataset are depicted in Table 4.

The next step was to ensure that the data is stationary and usable for panel analysis. For this, we did unit root testing with Augmented Dickey Fuller (ADF) values (Table 5). As seen in Table 5, the ADF values are all significant $(p<0.01)$, confirming the appropriateness of data for panel analysis.

The next test was to check for multicollinearity among variables. Since the preliminary correlation analysis revealed high correlation between certain variables, we did the variance inflation factor (VIF) for the variables within each industry (Table 6). The results showed some VIFs above 10, confirming multicollinearity. We therefore deleted these variables and reran the test for the remaining. The results were now satisfactory, with all VIFs below 10. Table 5 shows the results before and after multicollinearity analysis for each industry. The variables are now ready to be deployed into a regression model for each industry.

In panel analysis, the commonly used approaches include independently pooled model, fixed-effect model (also known as first differenced model), and random effect model. The equation for the independently pooled model is shown below:

Table 9 Comparison of fixed effects and random effects model for computer industry

\begin{tabular}{lll}
\hline Comparison results of fixed effects and random effects model & \\
\hline Hausman test & & \\
\hline chisq $=14.363$ & $\mathrm{df}=17$ & $p$ value $=0.6413$ \\
\hline
\end{tabular}


Table 10 Random effects model for the computer industry

\begin{tabular}{|c|c|c|c|c|}
\hline \multicolumn{5}{|l|}{ Random effects model } \\
\hline Coefficients: & Estimate & Std. error & $t$ value & $\operatorname{Pr}(>|t|)$ \\
\hline INTERCEPT & 5.708 & 1.0029 & 5.6913 & $0.00000001906^{* * *}$ \\
\hline BERD\% & 0.04068 & 0.25145 & 0.1618 & 0.871529 \\
\hline GOVERD\% & 2.8649 & 1.0004 & 2.8636 & $0.004323^{* *}$ \\
\hline GOVER_RESEACHER\% & -0.015821 & 0.01784 & -0.8868 & 0.37549 \\
\hline HERD\% & -1.0879 & 0.67842 & -1.6036 & 0.109294 \\
\hline HIGH_RESEARCHER\% & -0.0028366 & 0.0082533 & -0.3437 & 0.731188 \\
\hline PATENT_ICT & 0.00069838 & $4.823 e-05$ & 14.4809 & $<2.20 \mathrm{e}-16^{* * *}$ \\
\hline PATENT_TRIADIC & -0.000060034 & $8.828 \mathrm{e}-05$ & -0.68 & 0.496731 \\
\hline COOP_COINVENTOR\% & -0.00075916 & 0.0050732 & -0.1496 & 0.881094 \\
\hline COOP_OWN\% & -0.0096889 & 0.0060417 & -1.6037 & 0.10927 \\
\hline COOP_ABROAD\% & -0.013263 & 0.0042571 & -3.1156 & $0.001916^{* *}$ \\
\hline PATENT_ENV & -0.0024575 & 0.0001768 & -13.904 & $<2.20 \mathrm{e}-16^{* * *}$ \\
\hline INCOME_LEVEL & 0.14524 & 1.1914 & 0.1219 & 0.903013 \\
\hline OECD_MEM & -3.0259 & 1.2481 & -2.4243 & $0.015607^{*}$ \\
\hline GERD_GOV_PERFORM & -0.036709 & 0.018841 & -1.9484 & 0.051797 \\
\hline GERD_HIGH_PERFORM & 0.01069 & 0.013953 & 0.7661 & 0.443882 \\
\hline GERD_OTHER_FINANCE & -0.018753 & 0.019972 & -0.939 & 0.3481 \\
\hline GERD_GOV_FINANCE & -0.0096609 & 0.010862 & -0.8894 & 0.374113 \\
\hline GERD_ABROAD_FINANCE & -0.016215 & 0.0089331 & -1.8151 & 0.069961 \\
\hline PATENT_EPO & 0.000079401 & $3.614 \mathrm{e}-05$ & 2.1974 & $0.028345^{*}$ \\
\hline Adj. R-Squared: & 0.40962 & & & \\
\hline F-statistic: & 722.097 & p-value: & $<2.22 \mathrm{e}-16$ & \\
\hline
\end{tabular}

$$
y_{i t}=a+\sum_{K=2}^{K} \beta_{i t} x_{k i t}+\varepsilon_{i t}
$$

In this equation, $a$ represents the intercept, $\beta_{i t}$ represents the coefficient for each attribute, $x_{k i t}$ represents the attributes, and $\varepsilon_{i t}$ represents the residual of this model.

The equation for the fixed-effect model is as follows:

$$
y_{i t}=\lambda_{i}+\sum_{K=2}^{K} \beta_{i t} x_{k i t}+\varepsilon_{i t}
$$

In the equation above, $\lambda_{i}$ represents the intercept for each individual in the panel dataset, $\beta_{i t}$ represents the coefficient for each attribute, $x_{k i t}$ represents the attributes, and $\varepsilon_{i t}$ represents the residual of this model.

\begin{tabular}{|c|c|c|c|c|c|}
\hline \multicolumn{6}{|c|}{ Comparison Results of Pooling \& Fixed Effects Models for Aerospace Industry } \\
\hline \multicolumn{5}{|c|}{ F Statistic Test } & \multirow{3}{*}{$\begin{array}{c}\text { Results } \\
\text { Individual Fixed } \\
\text { Effects }\end{array}$} \\
\hline $\begin{array}{c}\text { Mixed Effects and } \\
\text { Individual Fixed Effects }\end{array}$ & $\begin{array}{c}\mathrm{F}= \\
374.12\end{array}$ & $\mathrm{df1}=39$ & $\mathrm{df} 2=613$ & $\mathrm{p}$-value $<2.2 \mathrm{e}-16$ & \\
\hline $\begin{array}{l}\text { Mixed Effects and Time } \\
\text { Fixed Effects }\end{array}$ & $\begin{array}{c}\mathrm{F}= \\
0.935\end{array}$ & $\mathrm{df} 1=15$ & $\mathrm{df} 2=637$ & $\mathrm{p}$-value $=0.5244$ & \\
\hline $\begin{array}{l}\text { Time Fixed Effects and } \\
\text { Individual Fixed Effects }\end{array}$ & $\begin{array}{c}\mathrm{F}= \\
594.3\end{array}$ & $\mathrm{df1}=24$ & $\mathrm{df} 2=613$ & p-value $<2.2 \mathrm{e}-16$ & $\begin{array}{c}\text { Individual Fixed } \\
\text { Effects }\end{array}$ \\
\hline
\end{tabular}

Table 11 Comparison of pooling and fixed effects models for aerospace industry 
Table 12 Test results of random effects for aerospace

\begin{tabular}{ccc}
\hline \multicolumn{3}{c}{ Test Results of Random Effects } \\
\hline L-M Test \\
\hline chisq $=337.61$ & $\mathrm{df}=16$ & p-value $<2.2 \mathrm{e}-16$ \\
\hline
\end{tabular}

The equation for the random-effect model is shown below:

$$
y_{i t}=\mathrm{a}+\lambda_{i}+\sum_{k=2}^{K} \beta_{i t} x_{k i t}+\varepsilon_{i t}
$$

In the equation, $a$ represents the intercept of the model, $\lambda_{i}$ represents the intercept for each individual in the panel dataset, $\beta_{i t}$ represents the coefficient for each attribute, $x_{k i t}$ represents the attributes, and $\varepsilon_{i t}$ represents the residual of this model. However, as seen from the results of the ADF test (Table 5), all the variables satisfied the stationary assumption, thereby eliminating the need for first-differenced models. We therefore decide on the final model through a two-step comparison between the pooling (mixed effects) and fixed effects model, and the fixed effects and random effects model. We first use the analysis of variance (ANOVA) $F$ test for both the time and country dimensions. Then, we use the L-M test to check for random effects, and the Hausman test to compare the leading influence of fixed or random effects models. We now discuss the regression analysis by industry.

\section{Regression analysis for the computer industry}

We first did a regression analysis on exports for the computer industry. Table 7 shows the results for the comparison of the pooling (mixed) and fixed effects models for the industry.

As shown in Table 7, the individual fixed effects model is better than the mixed effects model $(p<0.0001)$ and the time fixed effects model $(p<0.0001)$. We used the LM test (Table 8 ) to check for random effects, and the Hausman test (Table 9 ) to analyze the significance of the effects.

The LM test (Table 8) confirms the significance of the random effects $(p<0.0001)$. The results of the Hausman test (Table 9) indicate that the random effects model is better than the fixed effects model. Accordingly, we ran the random effects model for the computer industry (Table 10).

As Table 10 shows, five variables are significant in influencing exports: business expenditure (BERD), government expenditure (GOVERD), income level, gross expenditure on high education performance (GERD_HIGH_PERFORM), and patent

Table 13 Comparison of fixed effect and random effects model for aerospace

\begin{tabular}{ccc}
\hline \multicolumn{3}{c}{ Comparison Results of Fixed Effects \& Random Effects Model } \\
\hline \multicolumn{3}{c}{ Hausman Test } \\
\hline chisq $=64.663$ & $\mathrm{df}=17$ & $\mathrm{p}$-value $=1.752 \mathrm{e}-07$ \\
\hline
\end{tabular}


Table 14 Aerospace individual fixed effects model result

\begin{tabular}{ccccc}
\hline & Individual Fixed Effects Model & & \\
\hline Coefficients: & Estimate & Std. Error & t-value & $\operatorname{Pr}(>|\mathrm{t}|)$ \\
\hline BERD\% & 0.064092 & 0.14056 & 0.456 & 0.64857 \\
GOVERD\% & -0.20466 & 0.55431 & -0.3692 & 0.7121 \\
GOVER_RESEACHER\% & -0.00051493 & 0.0098304 & -0.0524 & 0.95824 \\
HERD\% & -0.24679 & 0.37315 & -0.6614 & 0.50862 \\
HIGH_RESEARCHER\% & -0.0086306 & 0.0045204 & -1.9092 & 0.0567. \\
PATENT_ICT & 0.000021772 & 0.000027428 & 0.7938 & 0.42762 \\
PATENT_TRIADIC & 0.00010152 & 0.000056348 & 1.8017 & 0.07209. \\
COOP_COINVENTOR\% & -0.00021297 & 0.0027485 & -0.0775 & 0.93826 \\
COOP_OWN\% & -0.00059873 & 0.0032748 & -0.1828 & 0.85499 \\
COOP_ABROAD\% & -0.00056032 & 0.0023347 & -0.24 & 0.81042 \\
PATENT_ENV & -0.00018556 & 0.000098719 & -1.8797 & 0.06062. \\
GERD_GOV_PERFORM & -0.00052976 & 0.010325 & -0.0513 & 0.9591 \\
GERD_HIGH_PERFORM & 0.0080144 & 0.0076257 & 1.051 & 0.29369 \\
GERD_OTHER_FINANCE & -0.0085196 & 0.010854 & -0.785 & 0.43279 \\
GERD_GOV_FINANCE & -0.0010707 & 0.0059412 & -0.1802 & 0.85704 \\
GERD_ABROAD_FINANCE & -0.00020917 & 0.0049146 & -0.0426 & 0.96607 \\
PATENT_EPO & $-2.1534 \mathrm{E}-05$ & 0.000020527 & -1.0491 & 0.29456 \\
\hline & & & & \\
\hline Adj. R-Squared: & -0.062183 & & \\
F-statistic: & 1.10106 & $\mathrm{p}$-value: & 0.34825 & \\
\hline
\end{tabular}

Table 15 Aerospace random effects model result

\begin{tabular}{|c|c|c|c|c|}
\hline \multicolumn{5}{|c|}{ Random Effects Model } \\
\hline Coefficients: & Estimate & Std. Error & t-value & $\operatorname{Pr}(>|t|)$ \\
\hline INTERCEPT & 0.72816 & 1.1082 & 0.657 & 0.511388 \\
\hline $\mathrm{BERD} \%$ & 0.014079 & 0.16027 & 0.0878 & 0.930028 \\
\hline GOVERD $\%$ & 0.085883 & 0.63333 & 0.1356 & 0.892175 \\
\hline GOVER_RESEACHER\% & -0.0059291 & 0.011246 & -0.5272 & 0.598237 \\
\hline HERD $\%$ & -0.23553 & 0.4271 & -0.5515 & 0.581513 \\
\hline HIGH_RESEARCHER\% & -0.0095139 & 0.0051787 & -1.8371 & 0.066646 \\
\hline PATENT_ICT & 7.5709E-06 & 0.000031072 & 0.2437 & 0.807571 \\
\hline PATENT_TRIADIC & 0.00016653 & 0.000061948 & 2.6883 & $0.007366 * *$ \\
\hline COOP_COINVENTOR\% & -0.0010017 & 0.0031561 & -0.3174 & 0.751047 \\
\hline COOP_OWN\% & -0.00020997 & 0.0037598 & -0.0558 & 0.955483 \\
\hline COOP_ABROAD $\%$ & -0.00074522 & 0.0026738 & -0.2787 & 0.780554 \\
\hline PATENT_ENV & -0.00014223 & 0.00011233 & -1.2662 & 0.205911 \\
\hline INCOME_LEVEL & 1.87 & 1.6058 & 1.1645 & 0.244642 \\
\hline OECD_MEM & 0.36702 & 1.6896 & 0.2172 & 0.828104 \\
\hline GERD_GOV_PERFORM & 0.00034554 & 0.011827 & 0.0292 & 0.976701 \\
\hline GERD_HIGH_PERFORM & 0.0055074 & 0.008741 & 0.6301 & 0.528872 \\
\hline GERD_OTHER_FINANCE & -0.0062295 & 0.012454 & -0.5002 & 0.61711 \\
\hline GERD_GOV_FINANCE & -0.00060817 & 0.0068089 & -0.0893 & 0.928855 \\
\hline GERD_ABROAD_FINANCE & -0.0019425 & 0.0056228 & -0.3455 & 0.729856 \\
\hline PATENT_EPO & $6.2502 \mathrm{E}-06$ & 0.000023328 & 0.2679 & 0.788838 \\
\hline Adj. R-Squared: & 0.022032 & & & \\
\hline F-statistic: & 1.79561 & p-value: & $<2.22 \mathrm{e}-16$ & \\
\hline
\end{tabular}


Table 16 Comparison of pooling and fixed effects models for pharmaceutical

\begin{tabular}{|c|c|c|c|c|c|}
\hline \multicolumn{6}{|c|}{ Comparison Results of Pooling \& Fixed Effects Model for Pharmaceutical Industry } \\
\hline \multicolumn{5}{|c|}{ F Statistic Test } & Results \\
\hline $\begin{array}{l}\text { Mixed Effects and Individual } \\
\text { Fixed Effects }\end{array}$ & $\mathrm{F}=231.75$ & $\mathrm{df1}=39$ & $\mathrm{df} 2=614$ & p-value $<2.2 \mathrm{e}-16$ & $\begin{array}{c}\text { Individual } \\
\text { Fixed Effects }\end{array}$ \\
\hline $\begin{array}{l}\text { Mixed Effects and Time Fixed } \\
\text { Effects }\end{array}$ & $F=0.636$ & $\mathrm{df} 1=15$ & $\mathrm{df} 2=638$ & $\mathrm{p}$-value $=0.8461$ & \\
\hline $\begin{array}{l}\text { Time Fixed Effects and } \\
\text { Individual Fixed Effects }\end{array}$ & $\mathrm{F}=370.66$ & df1 $=24$ & $\mathrm{df} 2=614$ & $\mathrm{p}$-value $<2.2 \mathrm{e}-16$ & $\begin{array}{l}\text { Individual } \\
\text { Fixed Effects }\end{array}$ \\
\hline
\end{tabular}

filings under EPO (PATENT_EPO). Of these, government expenditure is the most significant, since we see that a unit increase in government expenditure is associated with an almost 3-unit (2.8649) increase in exports. Time and country are significant influencers in this industry, along with government and business expenditure, income level, and educational performance. Even though patents have a positive influence on the final exports, the low coefficient (0.0000794) indicates that the effect is not as significant as for other variables.

\section{Regression analysis for the aerospace industry}

Table 11 shows the comparison between the pooling (mixed) and fixed effects models for the aerospace industry.

As shown in Table 11, the individual fixed effects model is better than mixed effects model $(p<0.0001)$. In comparing the mixed and time fixed effects models, we see that that time is not a significant influencer of exports in the industry. The results of the comparison between fixed effects models also support the conclusion that individual fixed effects model is better $(p<0.0001)$. Next, we performed the LM test to check for random effects (Table 12) and the Hausman test to compare the random and the fixed effects models (Table 13).

The results of the LM test (Table 12) show the random effects to be significant $(p<0.0001)$ in the analysis for the industry. The results of the Hausman test (Table 13) show the fixed effects model to be better than the random effects model $(p<0.0001)$.

We therefore ran a fixed effects model analysis for the aerospace industry (Table 14).

However, the results in Table 14 show that the model is not significant $(p>0.05)$ in explaining the relationships in the panel dataset for the industry. In light of this, we performed a random effects model analysis for the aerospace industry (Table 15).

In the random effects model shown in Table 15, the variables that have a positive influence on exports include business expenditure (BERD), government expenditure (GOVERD), income level, gross expenditure in the performance sector of higher education (GERD_HIGH_PERFORM), patent filings under EPO (PATENT_EPO), under ICT (PATENT_ICT), triadic patents (PATENT_TRIADIC), patents in environmental technology (PATENT_ENV), and OECD membership (OECD_MEM). In terms of patents,

Table 17 Test results of random effects for pharmaceutical

\begin{tabular}{ccc}
\hline \multicolumn{3}{c}{ Test Results of Random Effects } \\
\hline L-M Test \\
\hline chisq $=290$ & df $=16$ & p-value $<2.2 \mathrm{e}-16$ \\
\hline
\end{tabular}


Table 18 Comparison of fixed effects and random effects models for pharmaceuticals

\begin{tabular}{l} 
Comparison results of fixed effects and random effects model \\
Hausman test \\
\hline chisq $=24.539$ \\
\hline
\end{tabular}

we see that all four types of patents have a positive influence on exports and the influence is much higher here than in the computer industry. Income-level and OECD status (being a member) show a positive influence on exports in this industry.

\section{Exports analysis for the pharmaceutical industry}

The comparison between the fixed and mixed effects for the pharma industry (Table 16) shows that the individual fixed effects model is better $(p<0.0001)$. Time does not seem to be a significant factor in this industry $(p>0.05)$. In the comparison between the fixed effects models, the results also support the conclusion that individual fixed effects model is better $(p<0.0001)$.

We did the LM test to see if random effects are significant (Table 17) and the Hausman test to compare the random and fixed effects models (Table 18).

From the LM test results (Table 17), we see that the random effects are better $(p<0.0001)$, and from the Hausman test (Table 18), we see that the random effects model better explains the relationships in this industry. Accordingly, we did the random effects model for the pharma industry (Table 19).

The results in Table 19 show that patents, in terms of the number of applications, as well as ownership and funding from abroad, play a more prominent role in exports of this industry than in the others.

Table 19 Pharmaceutical random effects model result

\begin{tabular}{|c|c|c|c|c|}
\hline \multicolumn{5}{|c|}{ Random Effects Model } \\
\hline Coefficients: & Estimate & Std. Error & t-value & $\operatorname{Pr}(>|t|)$ \\
\hline BERD \% & -0.15442 & 0.13441 & -1.1489 & 0.2511 \\
\hline GOVERD $\%$ & 0.52175 & 0.53933 & 0.9674 & 0.3337 \\
\hline GOVER_RESEACHER\% & -0.0076268 & 0.0095507 & -0.7986 & 0.4249 \\
\hline HERD $\%$ & 0.14138 & 0.36227 & 0.3902 & 0.6965 \\
\hline HIGH_RESEARCHER\% & -0.0071347 & 0.0044006 & -1.6213 & 0.1055 \\
\hline PATENT_TRIADIC & $-7.5295 \mathrm{E}-05$ & 0.00004954 & -1.5199 & 0.1291 \\
\hline COOP_COINVENTOR\% & -0.00038225 & 0.0026749 & -0.1429 & 0.8864 \\
\hline COOP_OWN\% & 0.002605 & 0.0031707 & 0.8216 & 0.4116 \\
\hline COOP_ABROAD\% & 0.00055 & 0.0022682 & 0.2425 & 0.8085 \\
\hline PATENT_PHARMA & 0.0010062 & 0.00020088 & 5.0091 & $0.0000007157^{* * *}$ \\
\hline GERD_GOV_PERFORM & 0.011306 & 0.01003 & 1.1272 & 0.2601 \\
\hline GERD_HIGH_PERFORM & 0.00361 & 0.0073904 & 0.4885 & 0.6254 \\
\hline GERD_OTHER_FINANCE & -0.004941 & 0.010574 & -0.4673 & 0.6405 \\
\hline GERD_GOV_FINANCE & -0.0048652 & 0.0057844 & -0.8411 & 0.4006 \\
\hline$\underset{\mathrm{E}}{\mathrm{GERD} \text { ABROAD_FINANC }}$ & -0.00043541 & 0.0047836 & -0.091 & 0.9275 \\
\hline PATENT_EPO & 0.000019097 & 0.000018949 & 1.0079 & 0.3139 \\
\hline Adj. R-Squared: & 0.052506 & & & \\
\hline F-statistic: & 3.06576 & p-value: & $\begin{array}{c}0.00002103 \\
8\end{array}$ & \\
\hline
\end{tabular}


Table $\mathbf{2 0}$ Correlation coefficients and VIF test results

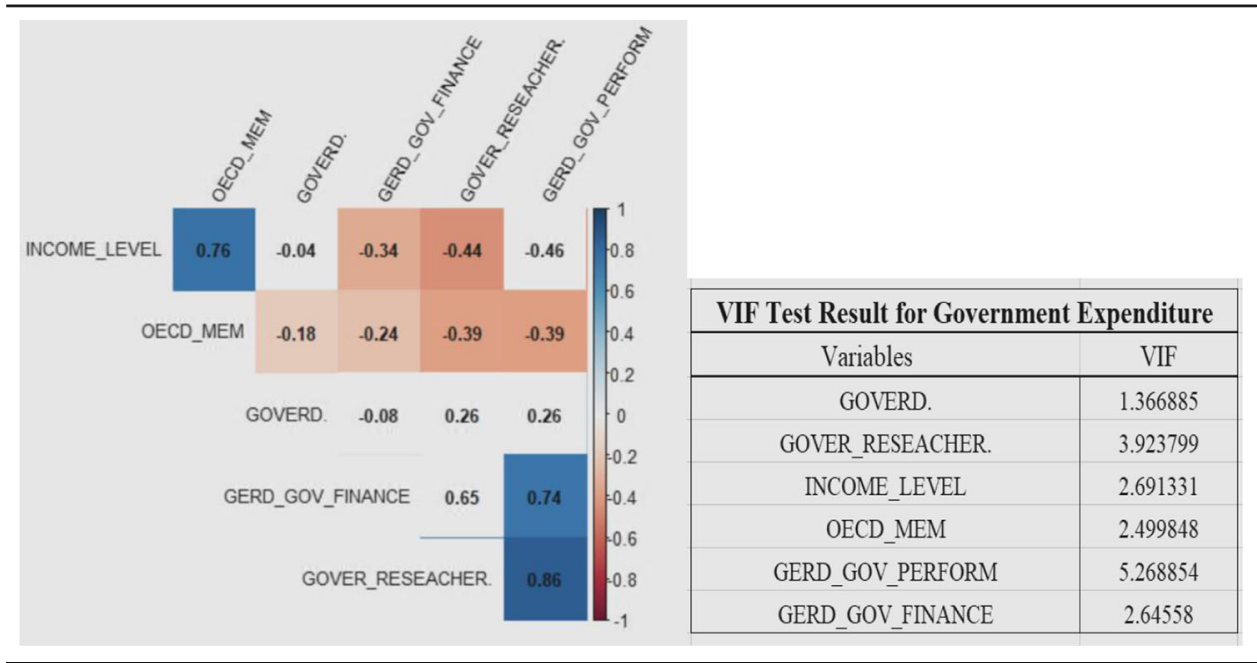

\section{Patents and government-related variables}

In this section, we analyze the relationship between the number of patent applications and the variables relating to government, such as expenditure and personnel. The dependent variable is the number of patents under PCT (PATENT_PCT). The six independent variables include GOVERD, GOVER_RESEARCHER, INCOME_LEVEL, OECD_MEM, GERD_GOV_PERFORM, and GERD_GOV_FINANCE. Using a correlation matrix, we found that most of the coefficients are less than 0.5 for the variables (Table 20). We also calculated the variance inflation factor (VIF) to test for multicollinearity (also shown in Table 20). The results of the table show all variables having a VIF of less than 5 , thereby indicating no multicollinearity.

Table 21 shows the comparison between the pooling (mixed) effects and the fixed effects models. The results indicate that the individual fixed effects model is better than both the mixed effects $(p<0.0001)$ and the time-fixed effects models $(p<0.0001)$.

We did the LM test (Table 22) and confirmed that the random effects model is significant $(p<0.0001)$ in this analysis. From the Hausman test (Table 23), we confirmed that the individual fixed effects model is better than the random effects model $(p<0.0001)$. Accordingly, we ran the individual fixed effects model for patents (Table 24).

The results of the individual fixed effects model (Table 24) show government expenditure on R\&D (GOVERD) and gross expenditure on R\&D in the government sector (GERD_GOV_PERFORM) as having a significant positive effect on the number of patent applications (PATENT_PCT). GOVERD, in particular, has a very large influence-a unit increase brings about 7040 unit increase in patents. This reflects

Table 21 Comparison of pooling and fixed effects models for pharma

\begin{tabular}{|c|c|c|c|c|c|}
\hline \multicolumn{6}{|c|}{ Comparison Results of Pooling \& Fixed Effects Model } \\
\hline \multicolumn{5}{|c|}{ F Statistic Test } & Results \\
\hline $\begin{array}{l}\text { Mixed Effects and Individual } \\
\text { Fixed Effects }\end{array}$ & $\mathrm{F}=374.12$ & $\mathrm{df1}=39$ & 613 & p-value $<2.2 \mathrm{e}-16$ & $\begin{array}{c}\text { Individual } \\
\text { Fixed Effects }\end{array}$ \\
\hline $\begin{array}{l}\text { Mixed Effects and Time Fixed } \\
\text { Effects }\end{array}$ & $\mathrm{F}=0.935$ & $\mathrm{df} 1=15$ & $\mathrm{df} 2=637$ & $\mathrm{p}$-value $=0.5244$ & \\
\hline $\begin{array}{l}\text { Time Fixed Effects and } \\
\text { Individual Fixed Effects }\end{array}$ & $F=594.3$ & $\mathrm{df} 1=24$ & $\mathrm{df} 2=613$ & $\mathrm{p}$-value $<2.2 \mathrm{e}-16$ & $\begin{array}{l}\text { Individual } \\
\text { Fixed Effects }\end{array}$ \\
\hline
\end{tabular}


Table 22 Comparison of pooling and random effects model

\begin{tabular}{ccc}
\hline \multicolumn{3}{c}{ Test Results of Random Effects } \\
\hline L-M Test \\
\hline chisq $=337.61$ & $\mathrm{df}=16$ & $\mathrm{p}$-value $<2.2 \mathrm{e}-16$ \\
\hline
\end{tabular}

the importance of government investment in $R \& D$ as a driving factor for patents and for innovation.

\section{International patents and gross expenditure on $R \& D$}

We now explore the influence of variables relating to gross expenditure on R\&D (GERD, GERD_BUS_PERFORM, GERD_GOV_PERFORM, GERD_OTHER_FINANCE, GERD_IND_FINANCE, GERD_ABROAD_FINANCE, and GERD_HIGH_PERFORM), on the percentage of patents owned by foreign residents (COOP_OWN). We checked for multicollinearity with the VIF test and resolved it by deleting the affected variables, and redoing the test. Table 25 shows the results before and after multicollinearity analysis.

Table 26 shows the comparison between pooling (mixed) and fixed effects models.

The results in Table 26 show that the fixed effects model is better $(p<0.0001)$ than the mixed effects model. Also, between the fixed effects model, the individual effects model is better $(p<0.0001)$. This means the influence of R\&D expenditure on patents varies among countries. On the contrary, the fixed effects model has no effect by time $(p>0.05)$. Table 27 shows the LM test, and Table 28 shows the Hausman test.

From the results of the LM test (Table 27), we see that the random effects model is significant $(p<0.0001)$. The Hausman test (Table 28) shows that the individual fixed effects model is good for this analysis $(p<0.0001)$. Therefore, we constructed the individual fixed effects model for the variables (Table 29).

According to the model results in Table 29, GERD financing from abroad (GERD_ABROAD_FINANCE) and gross expenditure on R\&D by higher education sector (GERD-HIGH-PERFORM) have negative coefficients. This is the case with business (BERD) and government expenditures (GOVERD) as well. Of the variables, government expenditure has the largest influence on patent ownership by foreign residents since a unit increase in government expenditure on $R \& D$ is associated with a decrease of 27.94 units in patents owned by foreign residents. This depicts a large impact.

In summary, a few things stand out from the panel analysis. First, it follows that the random effects model is better at explaining the relationship between exports and the independent variables in all the three industries. Time and country factors are significant in the model. Government expenditure on $R \& D$ has a positive influence on exports in all three industries (coefficients $=2.865,0.085$, and 0.563 respectively), implying that increased government expenditure will positively influence innovation through exports. Business expenditure, government expenditure, and gross expenditure in higher education are all key drivers for country-level innovation.

Table 23 Comparison of fixed and random effects model

\begin{tabular}{lll}
\hline Comparison results of fixed effects and random effects model & \\
\hline Hausman test & & \\
\hline chisq $=14.363$ & $\mathrm{df}=17$ & $p$ value $=0.6413$ \\
\hline
\end{tabular}


Table 24 Individual fixed effects model result

\begin{tabular}{lllll}
\hline Individual fixed effects model & & & & \\
\hline Coefficients: & Estimate & Std. error & $t$ value & $\operatorname{Pr}(>|t|)$ \\
\hline GOVERD\% & 7040.2247 & 2420.4771 & 2.9086 & $0.003759^{* * *}$ \\
GOVER_RESEACHER\% & -5.0068 & 44.4386 & -0.1127 & 0.910331 \\
GERD_GOV_PERFORM & -119.8164 & 45.9508 & -2.6075 & $0.009338^{* * *}$ \\
GERD_GOV_FINANCE & 6.0481 & 23.246 & 0.2602 & 0.794812 \\
Adj. R-Squared: & 0.022922 & & & \\
F-statistic: & 2.14624 & p-value: & 0.005758 & \\
\hline
\end{tabular}

Second, the computer industry has the largest $R$-square value among the three industries ( 0.41 in computer, 0.02 in Aerospace, and 0.005 in Pharmaceutical), indicating that the independent variables will have a stronger influence on exports in the computer industry than in the others. The results also point out that, of the three, investment of R\&D in the computer industry will have a stronger influence on national innovation.

Third, for all three industries, in terms of patents, government expenditure and government financing have a positive correlation with the number of patent applications. For instance, one unit increase in government expenditure (GOVERD) shows a 7040-unit increase in number of patent applications. This reflects the potential for government investment in $R \& D$ to influence innovative efforts.

Fourth, there is a negative correlation between $R \& D$ expenditure being financed from abroad and patents owned by foreign residents. This reflects the necessity for countries to ramp up internal financing for R\&D so as to encourage local innovation.

\section{Scope and limitations}

There are some limitations to our study. First, although we cover a period of 16 years, future studies can look at a longer span, facilitating the prospect of uncovering more trends and patterns in the data. Second, we explore associations but not causality in the relationships among S\&T indicators for innovation. Third, we consider a small segment of innovation indicators relating to $\mathrm{S} \& \mathrm{~T}$, whereas there is a gamut of variables that can be

Table 25 VIF tests before and after resolving multicollinearity

\begin{tabular}{|c|c|c|c|}
\hline \multicolumn{2}{|c|}{ Before multicollinearity analysis } & \multicolumn{2}{|c|}{ After multicollinearity analysis } \\
\hline Variables & VIF & Variables & VIF \\
\hline COOP_OWN\% & 2.342497 & COOP_OWN\% & 2.338598 \\
\hline GERD\% & 2610.814611 & GOVERD\% & 2.388626 \\
\hline GOVERD\% & 39.041936 & HERD\% & 3.02646 \\
\hline HERD\% & 124.939324 & BERD\% & 4.469952 \\
\hline BERD\% & 1860.667698 & GERD_GOV_PERFORM & 4.156039 \\
\hline GERD_BUS_PERFORM & 56.633482 & GERD_OTHER_FINANCE & 1.183356 \\
\hline GERD_GOV_PERFORM & 22.763118 & GERD_GOV_FINANCE & 2.755481 \\
\hline GERD_OTHER_FINANCE & 1102.518588 & GERD_ABROAD_FINANCE & 1.420166 \\
\hline GERD_GOV_FINANCE & 6401.936929 & GERD_HIGH_PERFORM & 3.677083 \\
\hline GERD_IND_FINANCE & 7809.030778 & & \\
\hline GERD_ABROAD_FINANCE & 2758.600606 & & \\
\hline GERD_HIGH_PERFORM & 36.270409 & & \\
\hline
\end{tabular}


Table 26 Comparison of pooling and fixed effects models

\begin{tabular}{|c|c|c|c|c|c|}
\hline \multicolumn{6}{|c|}{ Comparison Results of Pooling \& Fixed Effects Model in Business Expenditure } \\
\hline \multicolumn{5}{|c|}{ F Statistic Test } & Results \\
\hline $\begin{array}{c}\text { Mixed Effects and } \\
\text { Individual Fixed Effects }\end{array}$ & $\mathrm{F}=11.14$ & $\mathrm{df1}=39$ & $\mathrm{df} 2=622$ & $\mathrm{p}$-value $<2.2 \mathrm{e}-16$ & $\begin{array}{c}\text { Individual } \\
\text { Fixed Effects }\end{array}$ \\
\hline $\begin{array}{l}\text { Mixed Effects and Time } \\
\text { Fixed Effects }\end{array}$ & $\mathrm{F}=1.026$ & $\mathrm{df} 1=120$ & $\mathrm{df} 2=528$ & p-value $=0.4169$ & \\
\hline $\begin{array}{l}\text { Time Fixed Effects and } \\
\text { Individual Fixed Effects }\end{array}$ & $\mathrm{F}=1.829$ & $\mathrm{df1}=328$ & $\mathrm{df} 2=294$ & $\mathrm{p}$-value $=7.95 \mathrm{e}-08$ & $\begin{array}{c}\text { Individual } \\
\text { Fixed Effects }\end{array}$ \\
\hline
\end{tabular}

incorporated in future research. Fourth, the data are extracted from a secondary data source (OECD); the aggregated data from multiple sources/models inherently poses some limitations. For instance, data is missing for some years or regions-either it was not collected, or it was collected but not reported. We use patents as an indicator of innovation, but patents are subject to certain drawbacks. Many inventions are not patented, or inventors utilize alternative methods of protection such as secrecy and lead-time. Furthermore, the propensity for patenting varies across countries and industries. Differences in patent regulations and laws pose a challenge for analyzing trends and patterns across countries and over time.

\section{Contributions and future research}

Despite the limitations, our study contributes in many ways to the literature on innovation and policy making. While most studies adopt a firm or enterprise level of innovation analysis, we deploy a country-level analysis using a large and comprehensive dataset from the OECD. The breadth of the indicators in the dataset allows for in-depth multi-dimensional analysis. We utilize a dual methodology of visualization and panel analysis, each of which offers a suite of benefits in terms of research insights and knowledge on a phenomenon. Visualization is an assumption-free and data-driven approach, allowing the data to speak for itself. With no pre-conceived notions, the methodology allows for previously undetected patterns and relationships to emerge from the data. Panel analysis provides the researcher with a large number of data points and reduces the issue of multicollinearity among the explanatory research variables. It therefore improves the efficiency of econometric estimates and allows for multidimensional investigation of a phenomenon. In addition to the contributions in terms of methodologies, the research adds to the literature on empirical innovation studies that deploy an analytic approach. By comparing innovation indicators at a national level, this study calls on policy makers to design appropriate horizontal or vertical S\&T policies. The analysis of R\&D expenditure by sector and by industry, along with $R \& D$ personnel, allows for effective and optimum resource allocation and talent distribution. Patent analysis is done incorporating individual applications as well as triadic families, thereby offering an individual and holistic perspective. The study presents insights on the phenomenon of international

Table 27 Comparison of pooling and random effects model

\begin{tabular}{ccc}
\hline \multicolumn{3}{c}{ Test Results of Random Effects } \\
\hline L-M Test \\
\hline chisq $=52.228$ & $\mathrm{df}=16$ & $\mathrm{p}$-value $=1.006 \mathrm{e}-05$ \\
\hline
\end{tabular}


Table 28 Comparison of fixed effects and random effects models

\begin{tabular}{lll}
\hline Comparison results of fixed effects and random effects model & \\
\hline Hausman test & $d f=8$ & $p$ value $=9.283 e-09$ \\
\hline chisq $=53.336$ & $d$
\end{tabular}

collaboration in the inventive process. By focusing on cross-border ownership of patents, the study highlights the international flow of knowledge and research funds between countries, offering valuable lessons for global policy making for innovation.

While the study offers a panorama of results for innovation using S\&T indicators, more theoretical and empirical work is needed to further advance our understanding of country-level innovation. An important direction for future work is to incorporate other forms of IP in addition to patents in analyzing national innovation. More research is needed in terms of analyzing the relationship to important policy concepts and their performance in different domains. We view the culture in innovation a particularly fertile area. It is not only important for a nation to be creative in imagining, developing, and commercializing new technologies, products, and services, but also to be scalable in terms of attitudes towards adapting to change and willingness to take risks (Hofstede 2001; Strychalska-Rudzewicz 2016).

\section{Conclusions}

Our analysis shows differences between developed (high income) and developing (middle income) countries in terms of sectoral R\&D expenditure. While in developing countries, R\&D expenditure is predominantly from the government sector, in developed countries, it is from the business sector. As a nation develops, governmental expenditure on $R \& D$ decreases. Businesses and education take on greater roles to fill the gap. It is no surprise that most higher education institutions receive funding from governments and businesses.

The analysis of patents offers interesting revelations. Countries (such as the USA, Japan, Germany, and France) with a high share of patents (individual and patent families) show a low percentage of patents owned by foreign residents. The portfolio of

Table 29 Fixed effects model result

\begin{tabular}{|c|c|c|c|c|}
\hline Coefficients & Estimate & Std. error & $t$ value & $\operatorname{Pr}(>|t|)$ \\
\hline GOVERD\% & -27.9377771 & 8.155297 & -3.4256 & $0.00006538^{* * *}$ \\
\hline HERD\% & 8.9771973 & 4.5016897 & 1.9942 & 0.46568 \\
\hline BERD\% & -2.0725344 & 1.3753207 & -1.5069 & 0.1323321 \\
\hline GERD_GOV_PERFORM & 0.2455961 & 0.1289489 & 1.9046 & 0.0572931 \\
\hline GERD_OTHER_FINANCE & 0.0029454 & 0.0888257 & 0.0332 & 0.9735586 \\
\hline GERD_GOV_FINANCE & 0.2813369 & 0.0587816 & 4.7861 & $0.000002126^{* * *}$ \\
\hline GERD_ABROAD_FINANCE & -0.0388547 & 0.0766832 & -0.5067 & 0.6125508 \\
\hline GERD_HIGH_PERFORM & -0.3919284 & 0.0961369 & -4.0768 & $0.00005159^{* * *}$ \\
\hline Adj. R-squared & 0.020855 & & & \\
\hline F statistic & 7.91149 & $p$ value $3.61 \mathrm{e}-10$ & & \\
\hline
\end{tabular}


local versus foreign resident ownership of patents offers major implications for taxation and innovation policies at a national level. Countries with high foreign ownership of patents have low tax revenues as a percentage of GDP (Raghupathi and Raghupathi 2017). This is due to the fact that patents can be granted in countries other than those in which they were created, primarily because of the lack of associated costs and because income from IP is mobile (Griffith et al. 2014).

Naturally, multinational companies routinely search for tax havens to locate their IP (Lipsey 2010). In order to spur more local innovation, countries with a large percentage of patents with foreign ownership introduce "patent boxes" that lower the tax rate on income derived from patents. For example, Belgium reduced the tax rate from 34 to $6.8 \%$ in 2007, Netherlands from 31.5 to $10 \%$ in 2007, Luxembourg from 30.4 to $5.9 \%$ in 2008 , and the UK from 30 to $24 \%$ in 2013 (Griffith et al. 2014). We call on countries that have a high proportion of foreign ownership of patents to devise policies and incentives to encourage ownership by local residents and boost innovation and tax revenues.

Exports are an important aspect of innovation, and there is a relationship between exports and RD expenditure in an industry. A high level of expenditure on R\&D enables more exports by meeting higher standards, while a high level of exports allows countries to recover sufficient capital to focus on R\&D. Countries' promotion efforts for exports should parallel ways to maximize innovation creation and economic development (Leonidou et al. 2011). Policy makers need to recognize that the extent of experience within a country affects which factors influence high-technology exports. Additionally, different innovation characteristics can be identified and encouraged to support national innovation.

Lastly, countries need to reinstate horizontal and vertical S\&T policies for innovation (Niosi 2010). Horizontal policies apply equally to all sectors (e.g., tax credit for R\&D). While these policies are easy to implement and can strengthen existing sectors, they do not contribute to creation of new sectors. For new sectors to emerge, specifically high technology ones that contribute to growth, resources have to be concentrated in that direction. This is very important for developing countries that are looking to reap comparative advantages in targeted sectors. These countries need to develop and apply vertical policies directed to selected sectors. Since we show in our analysis that the ICT sector takes the lead in the number of patents over the years for most countries, it would be worthwhile to target resources and efforts in this sector to boost national innovation. Stimulating local innovation lowers both a dependence on foreign collaboration and foreign patent ownership. This holds promise for countries looking to enhance the contribution to GDP. Additionally, with globalization, economies are moving towards service-based and knowledge-based industries that are primarily ICT-driven, encouraging new patterns of growth and innovation (Raghupathi et al. 2014).

Countries can attain a level of endogenous innovation using multifaceted incentives for science and technology indicators. However, these policies and reforms need to be constantly evaluated and revised in light of the evolutionary economic and educational infrastructure. We propose a call on countries to design sophisticated national innovation ecosystems that integrate disparate policies of science, technology, finance, education, tax, trade, intellectual property, government spending, labor, and regulations in an effort to drive economic growth by fostering innovation. 


\begin{abstract}
Abbreviations
IP: Intellectual property; OECD: Organisation for Economic Cooperation and Development; R\&D: Research and development; S\&T: Science and technology
\end{abstract}

\title{
Acknowledgements
}

Not applicable.

\section{Funding}

There was no funding for the research.

\section{Availability of data and materials}

The datasets supporting the conclusions of this article are available in the OECD repository, https://stats.oecd.org.

\section{Authors' contributions}

Both authors read and approved the final manuscript.

\section{Authors' information}

Viju Raghupathi is an Associate Professor at the Koppelman School of Business, Brooklyn College of the City University of New York. She received her PhD in Information Systems from The Graduate Center, City University of New York. Her research interests include business analytics, social media, big data, innovation/entrepreneurship, sustainability, corporate governance, and healthcare. She has published in academic journals including Communications of the AlS, Journal of Electronic Commerce Research, IEEE Access, Health Policy and Technology, International Journal of Healthcare Information Systems and Informatics, Information Resources Management Journal, and Information Systems Management. Wullianallur Raghupathi is a Professor of Information Systems at the Gabelli School of Business, Fordham University, New York; Program Director of the M.S. in Business Analytics Program; and Director of the Center for Digital Transformation (http://www.fordhamcdt.org/). He is co-editor for North America of the International Journal of Health Information Systems \& Informatics. He has also guest edited (with Dr. Joseph Tan) a special issue of Topics in Health Information Management (1999) and a special section on healthcare information systems for Communications of the ACM (1997). He was the founding editor of the International Journal of Computational Intelligence and Organizations (1995-1997). He also served as an Ad Hoc Editorial Review Board Member, Journal of Systems Management of the Association for Systems Management, 1996-1997. Prof. Raghupathi has published 40 journal articles and written papers in refereed conference proceedings, abstracts in international conferences, book chapters, editorials, and reviews, including several in the healthcare IT field.

\section{Competing interests}

The authors declare that they have no competing interests.

\section{Publisher's Note}

Springer Nature remains neutral with regard to jurisdictional claims in published maps and institutional affiliations.

\section{Author details}

${ }^{1}$ Koppelman School of Business, Brooklyn College of the City University of New York, 2900 Bedford Ave, Brooklyn, NY 11210, USA. ${ }^{2}$ Gabelli School of Business, Fordham University, 140 W. 62nd Street, New York, NY 10023, USA.

Received: 2 May 2018 Accepted: 22 November 2018

Published online: 24 January 2019

\section{References}

Adams, J. D., Chiang, E. P., \& Starkey, K. (2001). Industry-university cooperative research centers. The Journal of Technology Transfer, 26(1-2), 73-86.

Aghion, P., \& Howitt, P. (1998). Endogenous growth theory. Cambridge, MA: MIT Press.

Akcali, B. Y., \& Sismanoglu, E. (2015). Innovation and the effect of research and development (R\&D) expenditure on growth in some developing and developed countries. Procedia-Social and Behavioral Sciences, 195, 768-775.

Arrow, K. (1962). Economic welfare and the allocation of resources for invention. In: The Rate and Direction of Inventive Activity: Economic and Social Factors. Princeton University Press, Princeton, 609-626.

Audretsch, D. B., Link, A. N., \& Scott, J. T. (2002). Public/private technology partnerships: evaluating SBIR-supported research. Research Policy, 31(1), 145-158.

Blind, K., Bührlen, B., Kotz, C., Menrad, K., \& Walz, R. (2004). New products and services: analysis of regulations shaping new markets. Luxembourg: European Commission DG Enterprise.

Chen, Q. (2008). The effect of patent laws on invention rates: evidence from cross country panels. Journal of Comparative Economics, 36(4), 694-704.

Cohen, W. M. (2010). Fifty years of empirical studies of innovative activity and performance. Handbook of the Economics of Innovation, 1, 129-213.

Collins, S., \& Wakoh, H. (2000). Universities and technology transfer in Japan: recent reforms in historical perspective. The Journal of Technology Transfer, 25, 213-222.

Dechezlepre^tre, A., Me'nie're, Y., \& Mohnen, M. (2017). International patent families: from application strategies to statistical indicators. Scientometrics, 111, 793-828.

Eid, A. (2012). Higher education R\&D and productivity growth: an empirical study on high-income OECD countries. Education Economics, 20(1), 53-68. 
Expert Panel on Business Innovation. (2009). Innovation and Business Strategy: Why Canada Falls Short. Ottawa: Council of Canadian Academies Available at http://www.conferenceboard.ca/hcp/details/innovation/berd.aspx\#_ftn2, Retrieved Sept 24, 2017.

Falk, M. (2006). What drives business research and d(R\&D) intensity across organisation for economic co-operation and development (OECD) countries? Applied Economics, 38, 533-547.

Furman, J. L., \& MacGarvie, M. J. (2007). Academic science and the birth of industrial research laboratories in the U.S. pharmaceutical industry. Journal of Economic Behavior \& Organization, 63, 756-776.

Gambardella, A., Harhoff, D., \& Verspagen, B. (2008). The value of European patents. European Management Review, 5(2), 69-84.

Gocer, I., Alatas, S., and Peker, O. (Winter 2016). Effects of R\&D and innovation on income in EU countries: new generation panel cointegration and causality analysis. Theoretical and Applied Economics, XXIII, 4(609), 153-164.

Görg, H., \& Strobl, E. (2007). The effect of R\&D subsidies on private R\&D. Economica, 74(294), 215-234.

Grady, R., \& Pratt, J. (2000). The UK technology transfer system: calls for stronger links between higher education and industry. The Journal of Technology Transfer, 25(2), 205-211.

Griffith, R., Miller, H., \& O'Connell, M. O. (2014). Ownership of intellectual property and corporate taxation. Journal of Public Economics, 112, 12-23.

Griliches, Z. (1980). R\&D and productivity slowdown. American Economic Review, 70, 343-348.

Grossman, G. M., \& Helpman, E. (1991). Innovation and growth in the global economy. Cambridge, MA: The MIT press.

Grossman, G. M., \& Helpman, E. (1995). Technology and trade. In G. M. Grossman \& K. Rogoff (Eds.), Handbook of international economics (Vol. 3). Amsterdam; New York: Elsevier.

Grupp, H., \& Mogeec, M. E. (2004). Indicators for national science and technology policy: how robust are composite indicators? Research Policy, 33, 1373-1384.

Hall, Bronwyn H. (Winter 2007). Patents and patent policy. Oxford Review of Economic Policy, 23(4), 568-587.

Harhoff, D. (2009). Economic cost-benefit analysis of a unified and integrated European patent litigation system. Final report to the European Commission http://ec.europa.eu/internal/_market/indprop/docs/patent/studies/litigation/_system/_en.pdf.

Harris, R. I., \& Moffat, J. D. (2012). R \& D, innovation \& exporting in Britain: an empirical analysis (pp. 1-43). University of Glasgow: Centre for Public Policy for Regions.

Hegde, D., Mowery, D. C., \& Graham, S. (2009). Pioneers, submariners, or thicket-builders: Which firms use continuations in patenting? Management Science, 55(7), 1214-1226.

Hobday, M. (1995). East Asian latecomer firms: learning the technology of electronics. World Development, 23, 1171-1193.

Hofstede, G. (2001). Culture's consequences: comparing values, behaviors, institutions and organizations across nations (2nd ed.). Thousand Oaks CA: Sage Publications.

Hu, A. G. Z., \& Jaffe, A. B. (2007). IPR, innovation, economic growth and development, Department of Economics, National University of Singapore.

Jaffe, A. B. (2000). The U.S. patent system in transition: policy innovation and the innovation process. Research Policy, 29, 531-557.

Kayal, A. A. (2008). National innovation systems: a proposed framework for developing countries. International Journal of Entrepreneurship and Innovation Management, 8(1), 74-86.

Kemp, R., \& Pearson, P. (2007). Final report of the MEl project measuring economic innovation. UM MERIT: Maastricht.

Khan, M., \& Khan, S. S. (2011). Data and information visualization methods, and interactive mechanisms: a survey. International Journal of Computer Applications (0975-8887), 34(1), 1-14.

Kim, S. Y. (2014). Government R\&D funding in economic downturns: testing the varieties of capitalism conjecture. Science and Public Policy, 41, 107-118.

Koh, W. T. H., \& Wong, P.-K. (2005). Competing at the frontier: the changing role of technology policy in Singapore's economic strategy. Technological Forecasting and Social Change, 72(3), 255-285.

Krugman, P. (1986). Pricing to market when the exchange rate changes. NBER Working Papers: National Bureau of Economic Research Inc.

Lee, Y. (2015). Evaluating and extending innovation indicators for innovation policy. Research Evaluation, 24, 471-488.

Leonidou, L. C., Palihawadana, D., \& Theodosiou, M. (2011). National export promotion programs as drivers of organizational resources and capabilities: effects on strategy, competitive advantage, and performance. Journal of International Marketing, 19(2), 1-29.

Lepori, B., Barre, R., \& Filliatreau, G. (2008). New perspectives and challenges for the design and production of S\&T indicators. Research Evaluation, 17(1), 33-44.

Lipsey, R. (2010). Measuring the location of production in a world of intangible productive assets, FDI, and intrafirm trade. Review of Income and Wealth, 56, 99-110.

Maksimovic, V., \& Phillips, G. (2008). The industry life cycle, acquisitions and investment: does firm organization matter? The Journal of Finance, 63(2), 673-708.

Malerba, F. (Ed.). (2004). Sectoral systems of innovation. Cambridge: Cambridge University Press.

Mazzoleni, R., \& Nelson, R. R. (2007). Public research institutions and economic catching up. Research Policy, 36(10), $1512-1528$.

Miles, M. B., \& Huberman, A. M. (1994). Qualitative data analysis: an expanded sourcebook. Thousand Oaks, CA: Sage Publications.

Moser, P. (Sept 2005). How do patent laws influence innovation? Evidence from nineteenth-century world fairs. American Economic Review, 95(4), 1214-1236.

Niosi, J. (2010). Rethinking science, technology and innovation (STI) institutions in developing countries. Innovation: Management, policy \& practice, 12, 250-268.

North, C. (2005). Toward measuring visualization insight. IEEE Computer Graphics and Applications, 11(4), 443-456.

Organisation for Economic Cooperation and Development OECD. (2009). Patent statistics manual. Paris: OECD http://dx.doi. org/10.1787/9789264056442-en. Retrieved 1 Oct 2017.

Organization for Economic Cooperation and Development (OECD). (1997). The measurement of scientific and technological activities, proposed guidelines for collecting and interpreting technological innovation data: Oslo manual (2nd ed.) http:// www.oecd.org/dataoecd/35/61/2367580.pdf . Retrieved Oct 15, 2017.

Organization for Economic Cooperation and Development (OECD). (2005). Guidelines for collecting and interpreting innovation data: Oslo manual (3rd ed.) http://unstats.un.org/unsd/EconStatKB/Attachment336.aspx?AttachmentType=1, Retrieved Oct 1, 2017.

Posner, M. V. (1961). International trade and technical change. Oxford Economic Papers, 13(3), 323-341. 
Qian, Y. (2007). Do additional national patent laws stimulate domestic innovation in a global patenting environment: a crosscountry analysis of pharmaceutical patent protection, 1978-2002. Review of Economics and Statistics, 89(3), 436-453.

Qiquan, Y., Changlin, G., Weiguo, S., \& Chen, W. (2006). Benchmarking national innovation capability: indicators framework and primary findings, OECD Workshop, Oct 19-20.

Raghupathi, V., \& Raghupathi, W. (2017). Innovation at country-level: association between economic development and patents. Journal of Innovation and Entrepreneurship, 6(4), 1-20. https://doi.org/10.1186/s13731-017-0065-0.

Raghupathi, W., Wu, S., \& Raghupathi, V. (2014). The role of information and communication technologies in global sustainability. Journal of Management for Global Sustainability, 2(1), 123-145.

Rajan, R. G., \& Zingales, L. (June 1998). Financial dependence and growth. American Economic Review, 88(3), 559-586.

Rostow, W. W. (1959). The stages of economic growth. The Economic History Review, 12(1), 1-16.

Sakakibara, M., \& Branstetter, L. (2001). Do stronger patents induce more innovation? Evidence from the 1988 Japanese patent law reforms. RAND Journal of Economics, 32, 77-100.

Schumpeter, J. A. (2008). The theory of economic development: an inquiry into profits, capital, credit, interest and the business cycle, New Brunswick (U.S.A) and London (U.K.): Transaction Publishers. Journal of Comparative Research in Anthropology and Sociology, 3, 137-148.

Siegel, D., Thursby, J., Thursby, M., \& Ziedonis, A. (2001). Organizational issues in university industry technology transfer: an overview of the symposium issue. The Journal of Technology Transfer, 26(1-2), 5-11.

Siyanbola, W., Adeyeye, A., Olaopa, O., \& Hassan, O. (2016). Science, technology and innovation indicators in policy-making: the Nigerian experience. Palgrave Communications. https://doi.org/10.1057/palcomms.206.15.

Strychalska-Rudzewicz, A. (2016). The impact of national culture on the level of innovation. Journal of Intercultural Management, 8(1), 121-145. https://doi.org/10.1515/joim-2016-0006.

Van Zeebroeck, N., \& van Pottelsberghe, B. (2011). Filing strategies and patent value. Economics of Innovation and New Technology, 20(6), 539-561.

Walwyn, D., \& Cloete, L. (2016). Universities are becoming major players in the national system of innovation. South African Journal of Science, $112(7 / 8), 121-128$.

World Economic Forum (WEF). (2012). The global competitiveness report 2012-2013. http://www3.weforum.org/docs/WEF GlobalCompetitivenessReport_2012-13.pdf, Retrieved Sep 29, 2017.

\section{Submit your manuscript to a SpringerOpen ${ }^{\circ}$ journal and benefit from:}

- Convenient online submission

- Rigorous peer review

- Open access: articles freely available online

High visibility within the field

- Retaining the copyright to your article

Submit your next manuscript at $\boldsymbol{s p r i n g e r o p e n . c o m ~}$ 